\title{
II.3. Novas estratégias de modelagem
}

Depois dos modelos propostos por Peirce e especialistas, apresentados nas seções anteriores, propomos estratégias de modelagem que podem ser empregadas na construção de novos diagramas. Os modelos analisados até aqui são, na maioria, monocromáticos, bidimensionais e/ou estáticos, características em grande medida impostas por limitações típicas do meio impresso. Estas características, contudo, não devem ser confundidas com limites intrínsecos das formas diagramáticas. Ao contrário, pesquisadores como Harel (1995: 263) sugerem a solução de problemas notacionais específicos através do uso de formalismos visuais tridimensionais e simulações gráficas dinâmicas. Sivasankaran e Owen (1992), por sua vez, são enfáticos sobre o poder investigativo de diagramas baseados em recursos de computação gráfica:

As restrições do formato convencional, estático e bidimensional dos diagramas, faz com que seja impossível para o usuário examinar mais do que uma série simples de relações de cada vez. A adição de uma terceira dimensão espacial utilizável, e do tempo como uma quarta dimensão, aumentam de modo considerável a utilidade de um diagrama enquanto ferramenta (SIVASANKARAN; OWEN 1992: 453).

\section{II.3.1. Modelos que utilizam cores}

Com exceção dos modelos de Olsen (1999, Figuras 31 e 32), Amadori (2001, Figura 34), Romanini (2006, Figura 39) e Borges (2010, Figura 40), nenhum dos diagramas apresentados nas seções anteriores utiliza recursos baseados em variações cromáticas. A introdução de cores (incluindo tons de cinza) permite, entre outras coisas, que o observador estabeleça relações entre elementos que se encontram espacialmente distantes no diagrama. Embora seja reconhecido como um aspecto importante das representações visuais, o uso da cor em diagramas é um tópico raramente abordado por pesquisadores em raciocínio diagramático. 
Anderson e Armen (1998) apresentam uma generalização da teoria do raciocínio inter-diagramático proposta por Anderson e McCartney (1995), ao incorporar o uso da cor como uma dimensão operacional. Esta teoria associa conhecimentos da teoria da cor ao estudo daquilo que pode ser processado computacionalmente a partir de representações diagramáticas. A estratégia consiste em associar valores de uma escala cromática aos elementos de um problema, e funções de combinação destes valores aos operadores que ajudam a definir e resolver um problema. Exemplos de aplicação fornecidos por Anderson e Armen (1998) incluem o agendamento de reuniões e a combinação de sequências de DNA. No agendamento de reuniões, a disponibilidade de cada participante a cada hora do dia é representada por um grau na escala de cor e a combinação destes fornece, para cada hora, um valor geral de disponibilidade. No caso do sequenciamento de DNA, as sequências de bases são representadas por sequências de tons em um sistema cromático, e as várias possibilidades de combinação de sequências são exploradas em termos de combinações de cores.

As Figuras 41 e 42 mostram como esta estratégia pode ser aplicada para representar as dez classes de signos em termos de cores nos sistemas RGB (vermelho, verde, azul) e CMY (ciano, magenta, amarelo). As Figuras 43 e 44 mostram o resultado da mesma estratégia aplicada às 66 classes, representadas como tripletos que indicam a quantidade de algarismos 1, 2 e 3 que compõem a notação numérica para cada classe. Nas Figuras 41 e 43, o sistema utilizado é o RGB. Em ambas, $R$ (vermelho) corresponde à categoria peirceana de primeiridade, $G$ (verde) à secundidade e $B$ (azul) à terceiridade. As classes são vistas como combinações de elementos destas três categorias, traduzidos em termos de quantidades de 1 s (primeiridades), 2s (secundidades) e 3s (terceiridades). As escalas graduadas acima dos diagramas indicam a correspondência entre a quantidade de elementos de uma determinada categoria em uma classe, e um ponto na escala de cor. Por exemplo, na Figura 41, duas terceiridades (como ocorre em 331 e 332) correspondem a 66\% de azul (ou 170 de B, em uma escala $R G B$ que vai de 0 a 255). Nas Figuras 42 e 44, onde o sistema utilizado é o CMY, as mesmas regras foram adotadas, mas $M$ (magenta) corresponde à primeiridade, $Y$ (amarelo) corresponde à secundidade e $C$ (ciano) corresponde à terceiridade. 

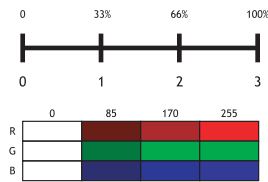

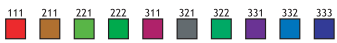

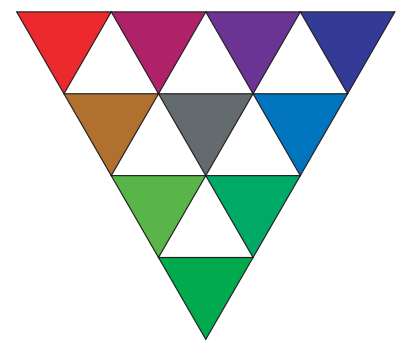

Figura 41. Diagrama para dez classes de signos, representadas como combinações de cores do sistema RGB.

$\begin{array}{lllllllllll}0 & 25 & 51 & 76 & 102 & 127 & 153 & 178 & 204 & 229 & 255\end{array}$

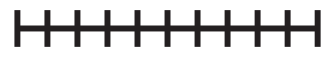

$\begin{array}{lllllllllll}0 & 1 & 2 & 3 & 4 & 5 & 6 & 7 & 8 & 9 & 10\end{array}$

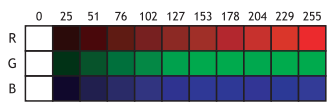

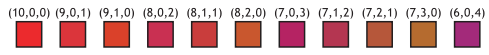

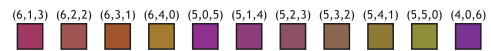
$(4,1,5)(4,2,4)(4,3,3)(4,4,2)(4,5,1)(4,6,0)(3,0,7)(3,1,6)(3,2,5)(3,3,4)(3,4,3)$ $(3,5,2)(3,6,1)(3,7,0)(2,0,8)(2,1,7)(2,2,6)(2,3,5)(2,4,4)(2,5,3)(2,6,2)(2,7,1)$ $\square \square \square \square \square \square \square \square \square \square \square$ $(2,8,0)(1,0,9)(1,1,8)(1,2,7)(1,3,6)(1,4,5)(1,5,4)(1,6,3)(1,7,2)(1,8,1)(1,9,0)$

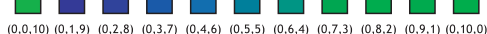

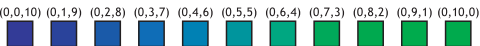

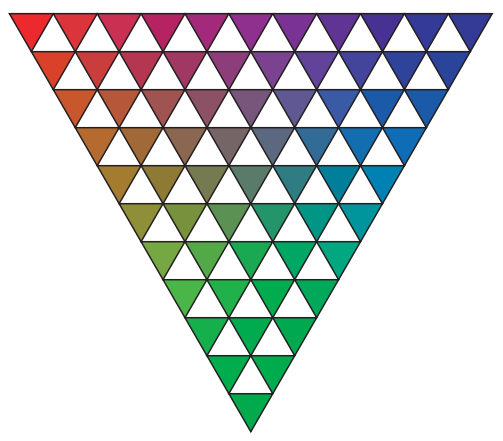

Figura 43. Diagrama para 66 classes de signos, representadas como combinações de cores do sistema RGB.

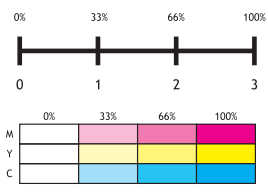

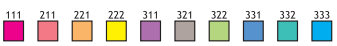

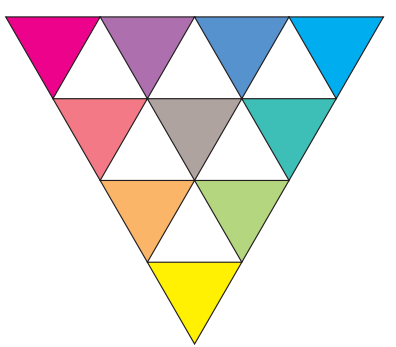

Figura 42. Diagrama para dez classes de signos, representadas como combinações de cores do sistema CMY.

$0 \% \quad 10 \% \quad 20 \%$ 30\% 40\% 50\% 60\% 70\% 80\% 90\% 100\%

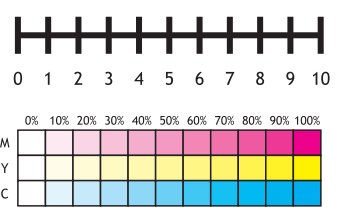

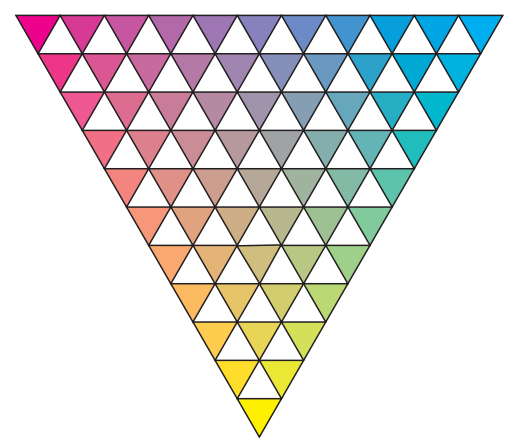

Figura 44. Diagrama para 66 classes de signos, representadas como combinações de cores do sistema CMY. 


\section{II.3.2. Modelos tridimensionais}

Os diagramas apresentados nas seções anteriores, com exceção dos modelos de Hoffman (2001, Figura 33) e Amadori (2001: 34, Figura 34), além de serem, em sua maioria, monocromáticos, são bidimensionais. Mesmo aqueles que simulam ou indicam uma terceira dimensão espacial (ver também o diagrama 3D de Balat, Figura 28), acabam sendo prejudicados por serem, de fato, representações bidimensionais e estáticas, próprias do meio impresso. Um dos cubos de Hoffman (o que corresponde à classe 321, ou SR6, Figura 33), por exemplo, tornou-se invisível devido ao arranjo do conjunto. No modelo de Amadori (Figura 34), a identificação numérica da classe 222 foi colocada sobre o cubo 311, à sua frente, contrariando as regras de perspectiva. As vantagens da inclusão de uma terceira dimensão espacial são melhor apreciadas em um ambiente tridimensional, em que o observador pode modificar sua posição em relação ao objeto observado.

Entretanto, certos cuidados devem ser tomados para que recursos tridimensionais não sejam interpretados de maneira equivocada ou pouco precisa. Diferenças de tamanho, por exemplo, podem ser interpretadas como diferenças de distância em relação ao observador. Bounford (2000: 80-83) demonstra como este problema pode ser, em alguns casos, contornado pelo uso de volumes gradeados, cujo tamanho pode ser mais facilmente comparado. A aplicação de cores em objetos tridimensionais também exige cuidados, uma vez que variações de intensidade (por exemplo, azul, azul escuro e azul claro) podem ser equivocadamente interpretadas como variações de sombra e luz. Isso ocorre, por exemplo, no cubo 333 do diagrama de Amadori (Figura 34), que pode ser visto como um objeto de uma só cor se não ficarmos atentos às legendas.

\section{Il.3.3. Modelos dinâmicos}

Todos os diagramas examinados até aqui são, sem exceção, representações estáticas, com as quais só podemos interagir sob o risco de deformá-las (ao fazer uma cópia errada, por exemplo) ou destruí-las (rasurá-las ou apagá-las). A inclusão de uma dimensão temporal não apenas facilita o entendimento de alguns diagramas (os modelos de Hoffman e Amadori comentados anteriormente, por exemplo, se beneficiariam), como permite a representação de outros tipos de relações.

A possibilidade de representar muitos níveis e tipos de relação, ao mesmo tempo, pode se tornar um problema caso não seja possível selecionar os tipos de relação que desejamos 
observar. Pode ser mais útil observar apenas um nível de relações, descartando detalhes de diferentes níveis. Harel (1995: 262) indica vantagens na capacidade de executar zoom outs, suprimindo detalhes menores, ao trabalhar com diagramas complexos. Em modelos estáticos, a única forma de se obter este efeito é observando diversas versões do mesmo diagrama. Em diagramas dinâmicos, através de recursos computacionais, este é apenas um dos muitos tipos de interação que podem ser implementados.

Em ambientes tridimensionais e dinâmicos, relações podem ser representadas por mudanças na posição e volume de objetos tridimensionais, além de mudanças na direção e forma de movimento. Relações que são representadas por meio de conexões orientadas, por exemplo (como nos diagramas de Balat e Marty, Figuras 26, 27, 28, 35 e 36), podem ser traduzidas em termos de movimento. Em diagramas que se transformam com o tempo, o exame dos processos desencadeados pode se basear em novas considerações: mudanças na configuração, ritmo das mudanças, sincronicidade etc.

Os diagramas dinâmicos apresentados a seguir são exemplos de como as estratégias indicadas podem ser aplicadas na construção de novos modelos para as classificações de signos de Peirce. Os diagramas foram desenvolvidos em 2001, no contexto de uma tese de doutorado (FARIAS 2002), e foram programados por Antonio Gomes. Eles estiveram em funcionamento, online, por cerca de dez anos. As seções seguintes funcionam aqui como uma detalhada documentação do desenvolvimento e aplicação destes modelos. ${ }^{34}$

\section{II.3.4. 10cubes: explorando a estrutura das dez classes de signos de Peirce}

10cubes é um aplicativo desenvolvido em linguagem Java, com o objetivo de modelar dinamicamente, através de recursos dinâmicos e interativos, as relações entre as dez classes de signos propostas por Peirce em seu "Syllabus" de 1903. Trata-se de um modelo tridimensional e interativo para ser manipulado em tempo real. ${ }^{35} \mathrm{O}$ projeto partiu da constatação de que havia diversas limitações dos modelos visuais para as classes e classificações e para os seus comentadores (em particular, MARTY 1990; BALAT 1990; MERRELL 1991, 1997; MARÓSTICA 1992; MÜLLER 1994). Estas limitações, de modo geral, estão relacionadas à natureza estática, bidimensional e monocromática destes modelos, características impostas pelas restrições encontradas nos processos tradicionais de impressão.
Embora nem sempre sejam compatíveis com os sistemas operacionais mais atuais, versões dos aplicativos, 10cubes e $3 \mathrm{~N}_{3}$ ainda podem ser acessadas a partir do verbete "Interactive diagrams for Charles Peirce's classifications of signs" no site The Digital Encyclopedia of Charles S. Peirce (FARIAS 2001b) e nestes endereços: <http://www.dca.fee.unicamp. br/ asrgomes/pri/dlocubes/>, $<$ http://www.dca.fee.unicamp. br/ asrgomes/pri/d3n3/>.

Os pressupostos para a construção deste diagrama foram detalhadamente expostos em Farias e Queiroz (2000a) e de forma um pouco mais resumida em Farias e Queiroz (2000b, 2000d). 


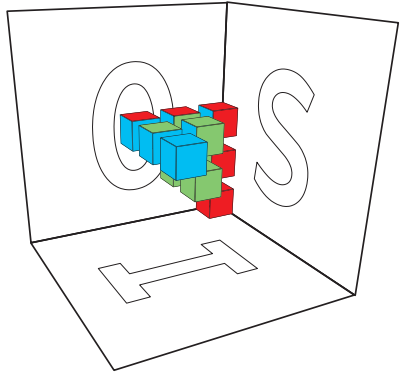

Figura 45. SANDERS I: Diagrama proposto por Priscila Farias e João Queiroz (2000a).

No artigo em que este diagrama é apresentado (BALAT 1990), o autor utiliza a nomenclatura "tom" (no original em francês, ton), "tipo" (type) e "traço" (trace), respectivamente, para definir o significado das as posições I, II e III.

37 As abreviaturas "S", "O" e "I", utilizadas para identificar as três tricotomias envolvidas na classificação de signos em dez classes proposta no "Syllabus" não devem ser confundidas com abreviaturas para os três correlatos do signo (Representamen, Objeto e Interpretante) descritos neste mesmo manuscrito, e que poderiam sugerir que a letra "R" fosse utilizada no lugar de "S" no diagrama aqui proposto.
Há boas razões para crer que, através dos recursos fornecidos pela computação gráfica e tecnologias digitais, pode-se obter uma nova família de diagramas, mais eficientes como ferramentas de investigação (ver FARIAS; QUEIROZ 2000a). Estas tecnologias permitem, por exemplo, a construção de diagramas em ambientes digitais tridimensionais, com atributos cromáticos e movimento. Em direta referência ao trabalho de Sivasankaran e Owen (1992), chamamos estes diagramas de "diagramas dinâmicos". Apresentamos a seguir algumas das principais questões que conduziram à elaboração e ao desenvolvimento do 10cubes, e avaliamos seus resultados.

\section{Conceitualização}

Como vimos em I.1.6, Peirce propõe, no "Syllabus", uma divisão dos signos em dez classes. Resumidamente, há três tricotomias, ou três aspectos segundo os quais a semiose pode ser observada: (i) signo em si mesmo, (ii) relação do signo com seu objeto, e (iii) relação do signo com seu interpretante. $\mathrm{O}$ cruzamento das três tricotomias forma uma matriz de nove células (três linhas por três colunas, ver Figura 9), a partir da qual Peirce extrai dez classes. Peirce descreve certas relações entre as classes, discutidas em I.1.3. A partir de tais descrições, Peirce e especialistas elaboram diagramas para a visualização destas relações. Contudo, como notamos, a maior parte destas construções exibe apenas as classes, ou as relações entre as tricotomias e categorias. O principal desafio enfrentado na implementação do 10cubes foi elaborar um diagrama através do qual pudéssemos observar tanto as relações entre as tricotomias e categorias quanto as relações entre as dez classes.

\section{Desenvolvimento - projeto de interface}

10cubes tem, como ponto de partida, uma estrutura de Michel Balat (1990: 86, Figura 28). O primeiro passo para a concepção de uma versão dinâmica deste modelo consistiu na elaboração de uma nova notação para as classes, envolvendo cores e volumes. Este diagrama (Figura 45) foi apresentado pela primeira vez sob o título de SANDERS I (FARIAS; QUEIROZ 2000a).

Diferente da maior parte dos diagramas elaborados para as classes de signos, o diagrama de Balat apresentado na Figura 28, embora de natureza bidimensional, sugere uma terceira dimensão. Neste diagrama, as três tricotomias que formam as dez classes são representadas por três eixos, ao longo dos quais estão dispostas as modalidades de primeiridade, secundidade e terceiridade. Estas modalidades são 
representadas por algarismos romanos (I, II, III), no eixo da primeira tricotomia; letras (A, B, C), no eixo da segunda tricotomia; algarismos arábicos $(1,2,3)$, no eixo da terceira tricotomia. No espaço interno destes eixos, a posição de cada classe é determinada por sua tradução em um conjunto de coordenadas $\langle\mathcal{x}, y, z\rangle$, onde $x$ corresponde a uma posição no eixo da primeira tricotomia $(\mathrm{I}=$ qualisigno, $\mathrm{II}=$ sinsigno, $\mathrm{III}=$ legisigno), ${ }^{36} y$ a uma posição no eixo da segunda ( $\mathrm{A}=$ ícone, $\mathrm{B}=$ índice, $\mathrm{C}=$ símbolo), e $z$ a uma posição no eixo da terceira tricotomia ( 1 = rema, 2 = dicente, 3 = argumento). $\mathrm{O}$ diagrama é desenhado de tal maneira que no ponto de intersecção entre os três eixos localiza-se a classe 111 (qualisigno), que corresponde à coordenada $<\mathrm{I}, \mathrm{A}, 1>$. Seguindo o mesmo princípio, a classe 211 (sinsigno icônico) posiciona-se logo acima, em < II, A, 1 >; 322 (legisigno indexical dicente) posiciona-se em < III, B, 2 >; 333 (argumento) posiciona-se em $<$ III, C, $3>$, e assim por diante.

Em SANDERS I (Figura 45), as classes foram mantidas nas mesmas posições relativas, embora identificadas de acordo com um novo formalismo visual. As tricotomias, antes representadas por três eixos em um sistema de coordenadas tridimensionais, passaram a ser representadas por três planos com uma interseção comum, identificados pelas letras $S$ (de Signo, abreviação para "Signo em si mesmo" ou "natureza do Signo", primeira tricotomia), O (de Objeto, abreviação para "relação do Signo com seu Objeto [Dinâmico]", segunda tricotomia), e I (de Interpretante, abreviação para "relação do Signo com seu Interpretante [Final]", terceira tricotomia). Dentro deste sistema de superfícies coordenadas, as classes passaram a ser representadas por cubos com faces paralelas aos planos S, O e I. ${ }^{37}$

As faces destes cubos foram coloridas diferentemente (vermelho para primeiridade, verde para secundidade e azul para terceiridade), ${ }^{38}$ de acordo com os tipos de relação $(1=$ primeiridade, 2 = secundidade e 3 = terceiridade) que constituem cada classe e o plano (S, O ou I) ao qual cada uma destas faces é paralela. Por exemplo, o cubo que corresponde à classe 321 teve suas faces paralelas ao plano $S$ pintadas de azul, aquelas paralelas ao plano $O$ pintadas de verde, e as paralelas ao plano I pintadas de vermelho. ${ }^{39}$ De acordo com o mesmo formalismo, o cubo que corresponde à classe 222 teve todas as suas faces pintadas de verde (Figura 46).

Uma consequência importante deste formalismo é que, mesmo sem considerarmos quais faces de um cubo são para-
A escolha das três cores primárias do sistema aditivo RGB (red, green, blue ou vermelho, verde, azul) para representar as categorias cenopitagóricas, em detrimento das três cores primárias do sistema subtrativo CMY (cyan, magenta, yellow, ou ciano, magenta, amarelo) deve-se ao fato deste (RGB) ser o sistema adotado pelas telas de computadores. Uma vez que o projeto SANDERS I previa, desde o início, a implementação do diagrama em meios digitais, considerou-se que o sistema RGB seria o mais adequado por ser mais coerente com esta implementação. Também seria possível, conforme discutido na Seção II.3.1, considerar a utilização de combinações de cores primárias para as diferentes faces dos cubos, mas isso se tornaria um problema para a representação dos volumes em três dimensões, em que estas combinações poderiam ser confundidas com a aplicação de sombras (algo similar ocorre no diagrama de Amadori [2001: 34], comentado na mesma seção).

A escolha das relações entre cores do sistema aditivo RGB e categorias cenopitagóricas segue a ordem em estas cores costumam ser apresentadas ( $\mathrm{l}=\mathrm{R}, 2=\mathrm{G}, 3=\mathrm{B})$. Mas não deixa de ser uma coincidência interessante o fato de um dos exemplos mais conhecidos de "qualisigno" (classe formada por três relações de primeiridade), fornecido pelo próprio Peirce, ser "um sentimento de vermelho" (CP 2.254).
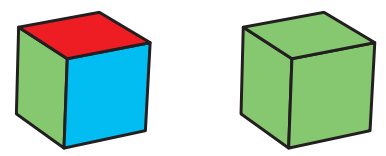

Figura 46. Os cubos que correspondem às classes 321 (à esquerda) e 222 (à direita), segundo o formalismo adotado em SANDERSI. 

variáveis da fórmula encontrada nesta página foram alteradas para torná-la coerente com a fórmula de Weiss e Burks (1945: 387) que será apresentada a seguir, tendo em vista uma maior clareza na explicação de sua equivalência. $\mathrm{Na}$ fórmula originalmente apresentada por Rosenstiehl, B corresponde ao número de palavras com $k$ letras que podem ser escritas com um alfabeto de $n$ letras. Em contraste com isso, na fórmula de Weiss e Burks $n$ corresponde ao número de tricotomias que formam uma classe (ou, nos termos de Rosenstiehl, ao número de letras de que formam uma palavra) dentro de uma classificação - sempre baseada no mesmo "alfabeto" de três letras, que corresponde às três categorias cenopitagóricas. Para evitar conflitos na nomeação das variáveis utilizadas nos próximos parágrafos, a fórmula de Rosenstiehl foi alterada de forma que a variável " $n$ " correspondesse, como na de Weiss e Burks, ao número de letras (ou número de tricotomias) que formam uma palavra (ou classe).

Isso significa, por exemplo, que ao calcular o número máximo de combinações de três elementos a partir de um alfabeto $\{R, G$, $B\}$, a combinação $(B, G, G)$ será considerada igual a $(G, B, C)$ e $(G$, $G, B)$, assim como a combinação

$(\mathrm{B}, \mathrm{C}, \mathrm{V})$ será considerada igual a qualquer outra combinação onde apenas a ordem dos elementos do alfabeto $\{R, G, B\}$ foi alterada.

42 A expressão " $C=$ " não faz parte da fórmula encontrada em Weiss e Burks (1945: 387) e foi incluída aqui para dar maior clareza à explicação a seguir. lelas a quais planos, quando três de suas faces estão visíveis é fácil perceber que cada cubo é um elemento diferente pois está colorido diferentemente. Isso ocorre porque, conforme leis da combinatória, se estamos trabalhando com apenas três cores, e se faces paralelas devem ter a mesma cor, existem apenas dez maneiras diferentes de colorir um cubo (Figura 47). Esta é uma demonstração visual da fórmula das aplicações crescentes de X em Y (ROSENSTIEHL 1988: 302): ${ }^{40}$

$$
C(k, n)=\left(\begin{array}{c}
k+n-1 \\
n
\end{array}\right)
$$

Esta fórmula permite calcular o número $C$ de combinações possíveis de $n$ elementos pertencentes a um alfabeto $k$, sem considerar a ordem destes elementos como fator de diferenciação. ${ }^{41}$ Note-se que, no caso das classes (combinações) criadas a partir das tricotomias, o valor de $k$ (número de elementos no alfabeto) não seria uma variável, mas uma constante igual a 3, pois 3 é o número de elementos que fazem parte de qualquer tricotomia. Esta fórmula assemelha-se àquela proposta por Weiss e Burks (1945: 387):

$$
C=(n+1)(n+2) / 2,{ }^{42}
$$

a partir da qual podemos calcular o número $C$ de classes que forma uma classificação de signos válida dentro do sistema peirceano a partir da determinação de um número $n$ de tricotomias.
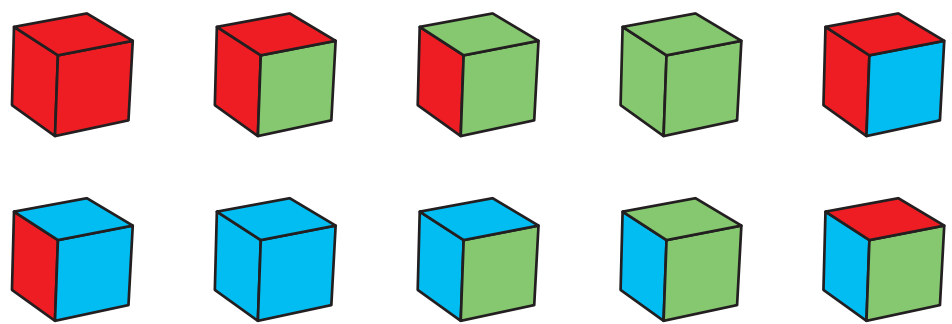

Figura 47. As dez únicas maneiras de se pintar as faces paralelas de um cubo utilizando três cores. Seguindo a mesma lógica da Figura 44, estes dez cubos podem ser colocados em correspondência com as dez classes de signos.

Definida uma notação para as classes, agora representadas por cubos coloridos, o próximo passo é determinar a melhor posição para estes cubos dentro dos planos do diagrama, preservando as posições relativas das classes. Ao observar um cubo em um espaço tridimensional, dependendo do ponto de vista, podemos enxergar apenas uma, duas, ou três de suas faces de 
cada vez. Além disso, ao observarmos um conjunto de cubos, é provável que alguns deles, dependendo de seu arranjo, estejam completa ou parcialmente escondidos por outros. Em SANDERS I a posição relativa dos cubos segue a posição das classes no diagrama de Balat (Figura 28), mas existe um espaço entre eles que facilita a visualização dos cubos mais distantes do observador. Conforme vimos em II.2.1., caso houvéssemos optado por um posicionamento dos cubos sem espaçamento entre eles, como em Hoffman (2000, Figura 33) ou em Amadori (2001: 34, Figura 34), perderíamos a capacidade de visualizar ao menos uma das faces de cada cubo (com exceção do cubo 333, em Amadori), mesmo tendo a possibilidade de girar o conjunto de cubos, conforme proposto em SANDERS I.

Previmos (FARIAS; QUEIROZ 2000a) que a possibilidade de girar o conjunto de cubos não apenas permitiria a visualização de todos, mas também facilitaria o estabelecimento de relações significativas entre grupos de classes. Poderíamos, por exemplo, observar o diagrama tendo à frente o plano $\mathrm{O}$ (Figura 48) e rapidamente perceber a existência de três grupos de cubos/classes: (i) aqueles com faces vermelhas paralelas a este plano (ícones), (ii) aqueles com faces verdes paralelas a este plano (índices), e (iii) aqueles com faces azuis paralelas a este plano (símbolos). O mesmo ocorreria ao observarmos o diagrama tendo à frente os planos S ou I (Figuras 49 e 50). Esta importante propriedade, também presente no diagrama quadrado de Balat (1990: 85, Figura 27, onde podemos observar nove grupos de classes formados pelas dez classes de signos), havia sido perdida em seu diagrama 3D (Figura 28).

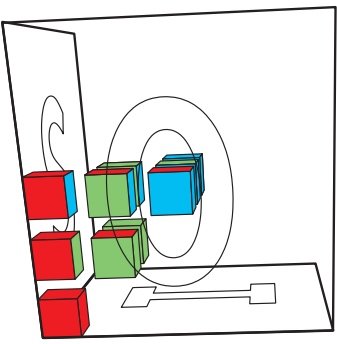

Figura 48. SANDERS I visto a partir do plano 0 . Com atenção às cores (vermelho, verde ou azul) das faces que são paralelas a este plano, é fácil observar a existência de três grupos especiais de cubos: ícones (à esquerda, em vermelho), índices (ao meio, em verde) e símbolos (à direita, em azul).

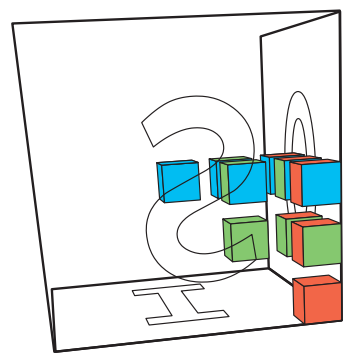

Figura 49. SANDERS I visto a partir do plano $S$. Com atenção às cores (vermelho, verde ou azul) das faces que são paralelas a este plano, é fácil observar a existência de três grupos especiais de cubos: qualisignos (abaixo, em vermelho), sinsignos (no meio, em verde), e legisignos (no alto, em azul).

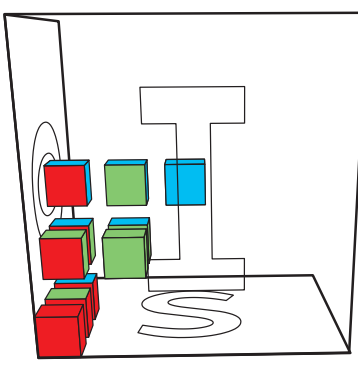

Figura 50. SANDERS I visto a partir do plano I. Com atenção às cores (vermelho, verde ou azul) das faces que são paralelas a este plano, é fácil observar a existência de três grupos especiais de cubos: remas (à esquerda, em vermelho), dicentes (ao meio, em verde), e argumentos (à direita, em azul). 
Figura 51. Storyboard com os seis passos principais das relações de instanciação e envolvimento entre as dez classes de signos. No sentido da leitura, temos: 1) $333 \ldots$

2) ...instância 332, que envolve 331 . 3) 332 instância 322, que envolve 321. 331 instância 321.

4) 321 envolve 311.

5) 322 instância 222, que envolve 221. 321 instância 221, que envolve 211. 311 instância $211, \ldots$

6) ... e 211 envolve 111 .
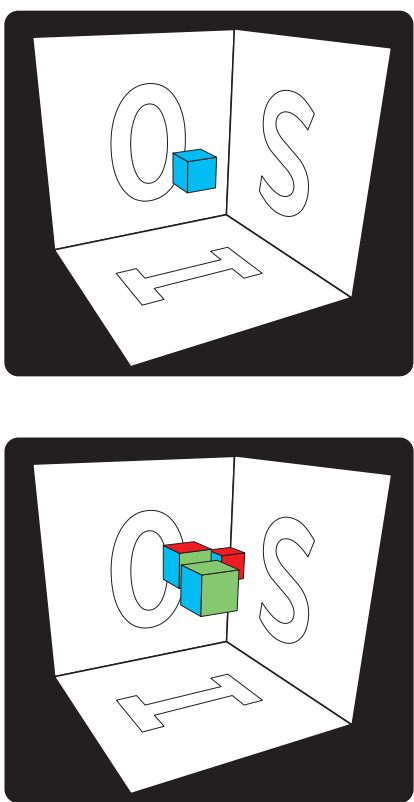

Neste contexto, pode-se afirmar que o arranjo específico de cubos, cores e posições de SANDERS I satisfazia boa parte dos objetivos do projeto, uma vez que permitia que observássemos tanto as relações entre as tricotomias (combinações de faces coloridas que formam os cubos) quanto um aspecto importante da relação entre as classes - a posição de cada classe em relação às demais, determinada em função das tricotomias e das modalidades cenopitagóricas (primeiridade, segundidade, terceiridade). Chamamos (FARIAS; QUEIROZ 2000b) estas relações de "relações estáticas" e afirmamos que o projeto não se limitaria a este tipo de relação. Conforme mencionado no primeiro parágrafo desta seção, pretendíamos construir um diagrama onde fosse possível visualizar também as relações entre as classes.

Para representar este tipo de relação, que chamamos de "relações dinâmicas", propusemos (FARIAS; QUEIROZ 2000a) a adoção de um conjunto de regras visuais envolvendo o aparecimento e o desaparecimento de cubos específicos, e diferenças nos tamanhos destes cubos. Para esclarecer melhor este ponto, elaboramos, como exemplo, um storyboard (Figura 51) contendo os principais passos das relações dinâmicas entre as dez classes que aparecem nos diagramas de Balat (Figuras 26, 27 e 28), na forma de conexões orientadas. Segundo uma interpretação de Serson (1997: 134-136), as relações representadas por estas setas podem ser divididas entre relações de "instanciação" e de "envolvimento".
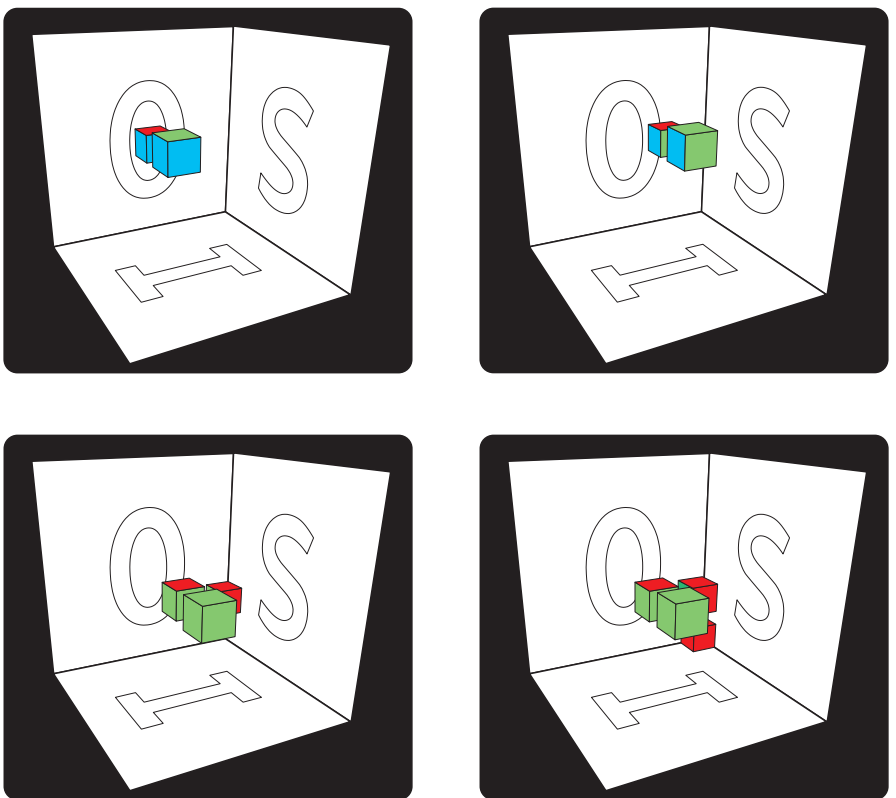
Neste storyboard, foram adotadas duas regras visuais para representar os dois tipos de relação: relações de instanciação estão representadas por uma substituição das classes "instanciadoras" pelas classes "instanciadas"; relações de envolvimento estão representadas pela aparição simultânea das duas classes relacionadas, as classes que envolvem estão representadas por cubos maiores do que as classes "envolvidas".

\section{Desenvolvimento - implementação}

A primeira versão de 10cubes foi baseada, principalmente, nas ideias indicadas em Farias e Queiroz (2000a), descritas nos parágrafos anteriores. Tratou-se de uma versão bastante simples e direta de SANDERS I: um modelo informático tridimensional, bastante similar ao da Figura 43, que podia ser girado em qualquer direção utilizando o recurso de clicar e arrastar com o mouse. A este modelo foi acrescentado um segundo recurso de interatividade que não estava previsto no projeto original: ao clicar sobre um cubo, este ficava destacado, com suas arestas em amarelo; uma legenda indicando a classe por ele representada aparecia logo acima do diagrama (Figura 52).

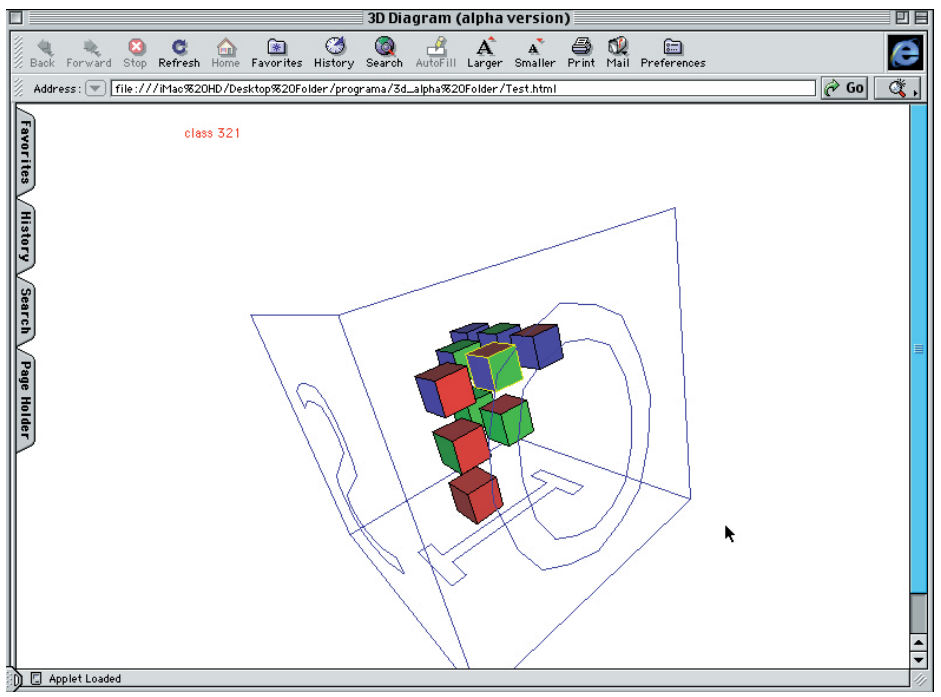

A partir da versão alpha-2, novos recursos foram adicionados. Em primeiro lugar, o recurso da legenda para os cubos/ classes foi aprimorado de forma que, além da descrição em termos numéricos (por exemplo, "321"), os cubos também fossem descritos verbalmente (por exemplo, "legisigno indexical remático"). Também ficou estabelecido que as cores utilizadas
Figura 52. Aspecto da interface de 10cubes, versão alpha-1, com o cubo que corresponde à classe 321 selecionado (arestas em amarelo). 
As tricotomias representadas pelo planos $\mathrm{S}, \mathrm{O}$ e I são descritas nestas legendas, respectivamente, como: SIGN/SIGN relation, SIGN/OBJECT relation e SIGN/INTERPRETANT relation. Deve ser fácil, para um usuário que possua alguma familiaridade com a divisão em dez classes proposta por Peirce, intuir que as duas últimas legendas são versões abreviadas de "relação do signo com seu objeto" e "relação do signo com o interpretante". A primeira legenda, contudo, merece uma explicação. Trata-se, obviamente, de uma tentativa de abreviação para a descrição verbal da primeira tricotomia. Peirce, assim como boa parte de seus comentadores, refere-se a esta tricotomia como "signo em si mesmo" (EP 2: 291, LIEB 1977: 160; WEISS; BURKS 1945: 385; HOUSER 1991: 433; MÜLLER 1994: 140), "modo de apreensão do signo em si mesmo" (EP 2: 482), "modo de apresentação do signo" (EP 2: 483), ou ainda "natureza do signo" (HOUSER 1991:

435). Neste contexto, a expressão "SIGN/SIGN relation" é uma tentativa de aproximar a descrição desta primeira tricotomia às descrições das outras duas, definindo-a em termos de uma 'relação do signo com si mesmo'. A escolha desta descrição se justifica se levarmos em consideração que, quando Peirce fala em "signo em si mesmo", ele provavelmente tem em mente algo similar ao conceito de identidade tal como descrito no primeiro capítulo de seu $A$ Guess at the Riddle (W 6: 165-210, W 6: 177). nas legendas, para ambas as formas de descrição, deveriam obedecer ao mesmo critério usado para colorir os cubos: vermelho para primeiridade, verde para secundidade, azul para terceiridade (Figura 53).

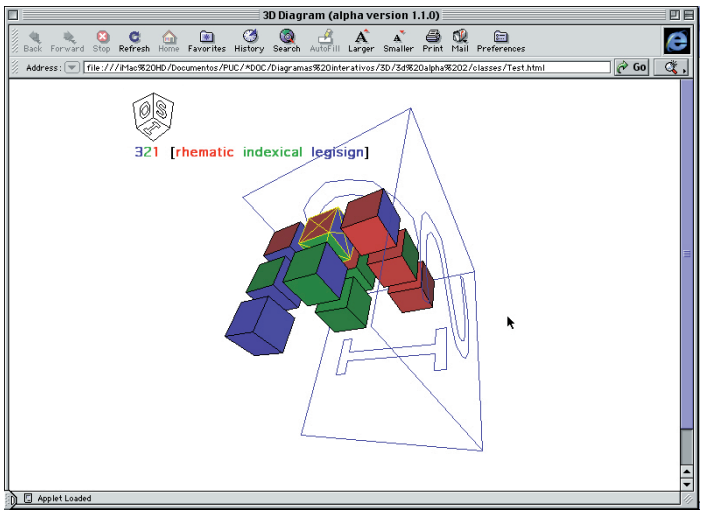

Figura 53. Aspecto da interface de 10cubes, versão alpha-2, com o cubo 321 selecionado (arestas e diagonais amarelas nas seis faces).

O próximo recurso adicionado foi um botão reproduzindo os três planos do diagrama (botão 'S/O/I'), criado para possibilitar "saltos diretos" para vistas especiais, sem a necessidade de girar o modelo. Ao clicar sobre um dos planos que formam este botão, saltamos de qualquer posição para uma vista do modelo que tem como plano principal (de frente para o usuário) o plano escolhido. Concomitantemente, ao lado do botão $\mathrm{S} / \mathrm{O} / \mathrm{I}$, observamos uma legenda que informa a tricotomia à qual o plano selecionado se refere (por exemplo, "relação SIGNO/OBJETO") ${ }^{43}$ e quais são suas modalidades (por exemplo, ícones, índices e símbolos). Ao clicar sobre uma destas modalidades, (por exemplo, "índices"), as faces dos cubos nas quais ela aparece (neste caso, 221, 222, 321 e 322) passam a ser sinalizadas (Figura 54).

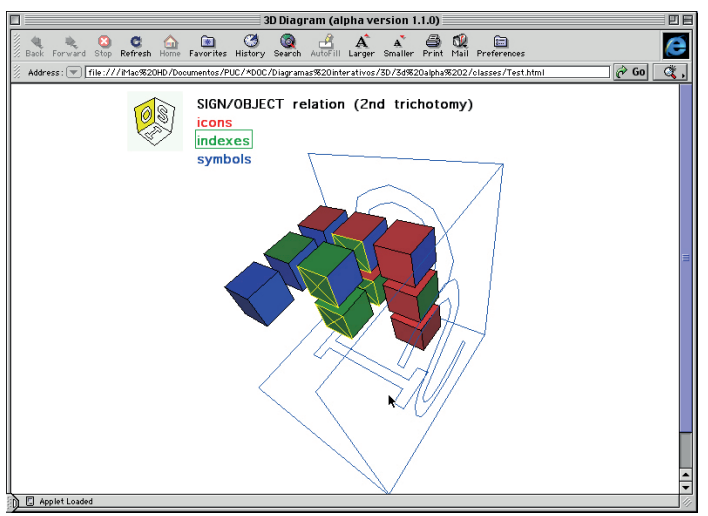

Figura 54. Aspecto da interface de 10cubes, versão alpha-2, com as faces dos cubos que correspondem aos índices selecionadas (contornos e diagonais em amarelo) 
A partir da versão alpha-5, estabeleceu-se uma diferença no modo de destacar um cubo selecionado, conforme se tratasse de uma seleção de modalidade ou de uma seleção de classe (por exemplo, sinsigno indexical remático). Para evitar confusões na leitura das legendas, as faces de cubos destacadas a partir das seleções "por modalidade" passaram a ser destacadas por traços amarelos em suas diagonais, enquanto os cubos selecionados diretamente passaram a ser destacados por traços amarelos sobre suas arestas (Figura 55).

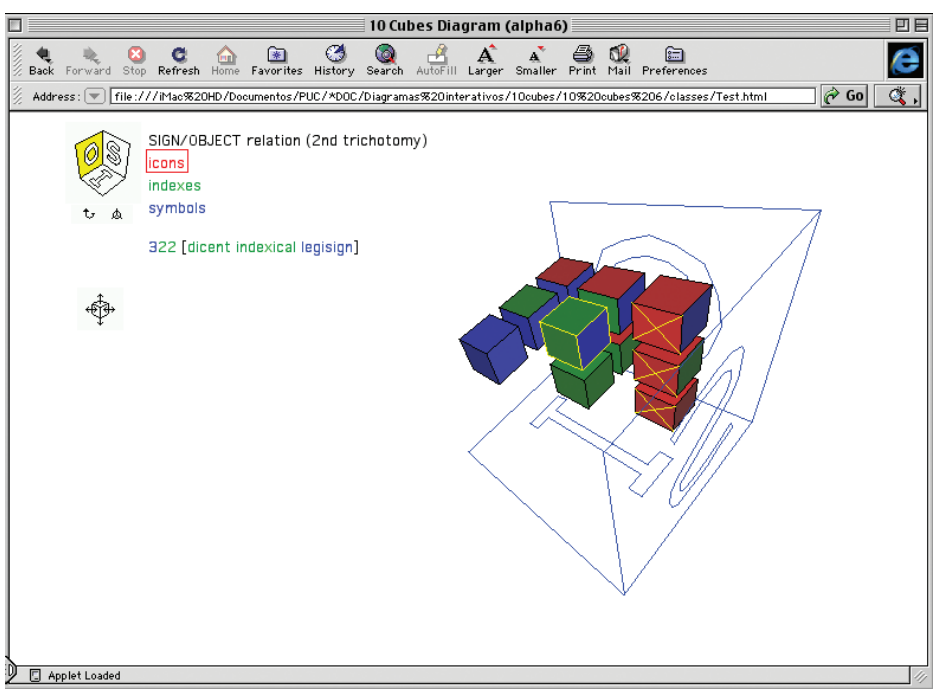

Além disso, outros botões e recursos foram adicionados. Logo abaixo do botão $\mathrm{S} / \mathrm{O} / \mathrm{I}$, foi inserido um pequeno botão em forma de flecha, fazendo o diagrama girar em 180 graus. À sua direita, um botão em forma de alvo faz o diagrama retornar à posição inicial, sem nenhum cubo ou legenda selecionados. Este mostra-se particularmente útil no caso de termos efetuado diversos giros e seleções diferentes durante a navegação e desejarmos retornar à posição inicial.

Abaixo deste grupo, um botão na forma de cubo dá acesso à visualização de duas sequências de relações dinâmicas entre as classes (Figura 56). O usuário pode optar entre visualizar as relações de "instanciação/envolvimento" (recurso previsto no projeto inicial) ou as relações de "implicação". Para estas últimas, que seguem a sequência de conexões orientadas que aparecem no diagrama proposto por Marty (1982a: 178, Figura 35), foi adotada uma regra visual segundo a qual as classes/cubos "implicadas" vão se tornando visíveis e fazendo com que se
Figura 55. Aspecto da interface de 10cubes, versão alpha- 6 , com as faces dos cubos que correspondem aos ícones (diagonais em amarelo), e o cubo que corresponde à classe 322 (arestas em amarelo) selecionados. 
44 A regra visual segundo a qual classes/cubos "que envolvem" seriam representadas por cubos maiores do que os das classes/cubos 'envolvidas', que complementava a aparição simultânea das classes no projeto original (ver os últimos parágrafos dedicados ao "Desenvolvimento projeto de interface", acima), foi abandonada devido ao fato da perspectiva tridimensional em movimento criar impressões erradas de volume. Este problema poderia ser minimizado pela adoção de cubos 'gradeados', mas este novo recurso visual traria uma complicação desnecessária à implementação do diagrama.

Figura 56. Aspecto da interface de 10cubes, versão alpha- 6 , com o botão Relations between classes selecionado (em amarelo).

Figura 57. Sequência de passos da relação Implication na versão alpha-7 de locubes. tornem também visíveis as classes/cubos que elas "implicam" (Figura 57). Para as relações de "instanciação/envolvimento", foram adotadas duas regras: (i) classes/cubos "instanciadores" são substituídas pelas classes/cubos "instanciados"; e (ii) classes/cubos "envolvidos" aparecem simultaneamente às classes/ cubos que envolvem ${ }^{44}$ (Figura 58).
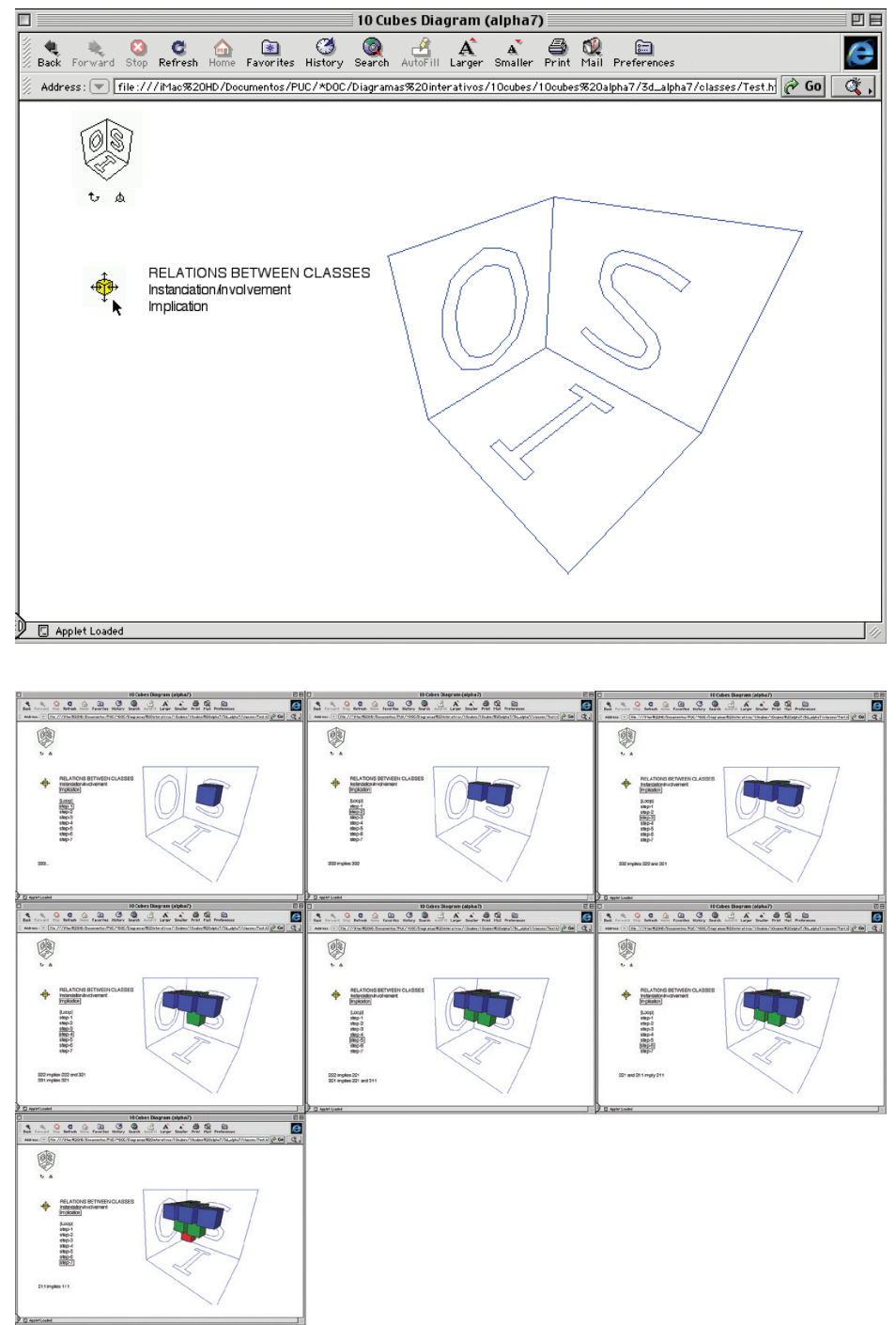


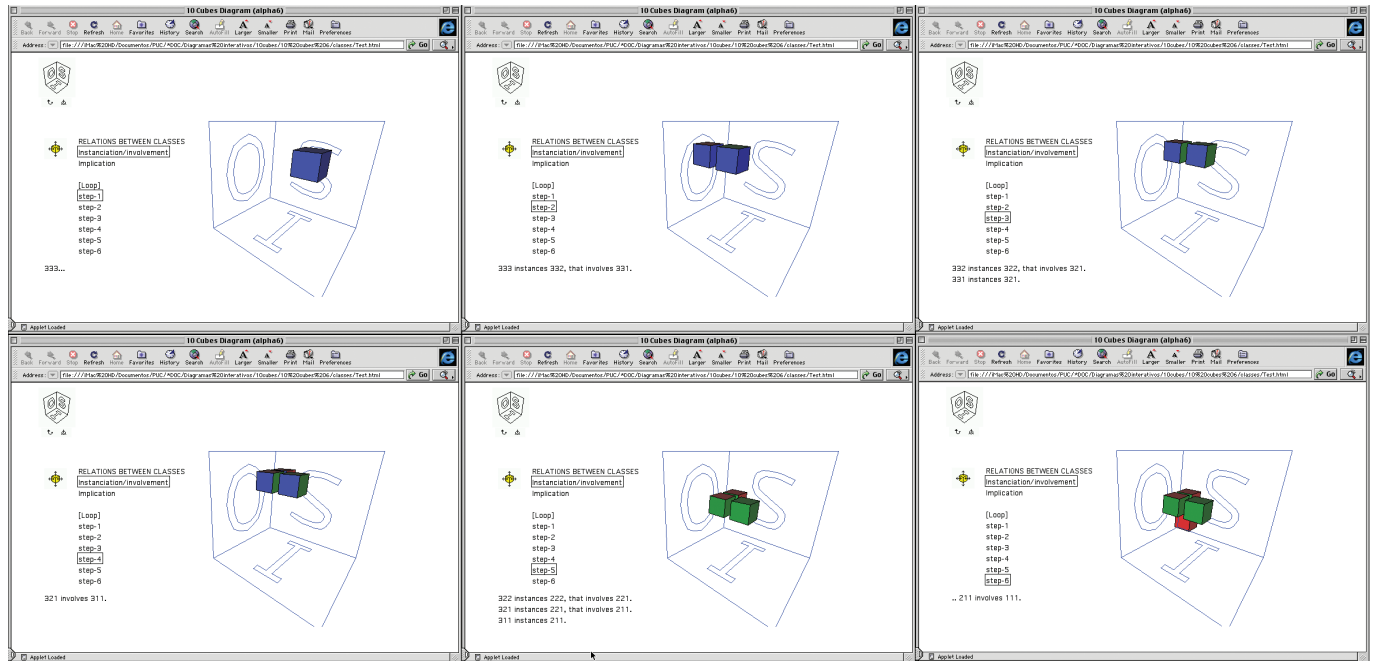

Nas duas sequências, é possível optar entre uma visualização em animação contínua (loop) e uma visualização passo-a-passo (clicando diretamente nos steps, ou passos que compõem cada sequência). Cada "passo" corresponde a uma configuração específica do diagrama, e sua descrição é fornecida em uma legenda abaixo (Figura 59). Mesmo neste modo de visualização "animado" é possível selecionar cubos (clicando diretamente sobre eles) e modalidades (clicando sobre uma modalidade dentro de uma lista de tricotomia). A Figura 60 mostra um exemplo da visualização obtida com o passo 6 da relação "instanciação/envolvimento", o cubo/classe 221, e a modalidade "ícone" selecionados. Somente os cubos que correspondem ao passo 6 da relação "instanciação/envolvimento" (111, 211 e 222) estão visíveis. O cubo que corresponde à classe 221 está com suas arestas realçadas (em amarelo), assim como as diagonais das faces dos cubos/classes 111 e 211 paralelas ao plano O, que correspondem aos ícones (o cubo/classe 311, que também possui uma face "icônica", não está visível neste passo da relação "instanciação/envolvimento").
Figura 58. Sequência de passos da relação Instantiation/involvement na versão alpha-6 de 10cubes. 
Figura 59. Aspecto da interface de 10cubes, versão alpha-6, com o passo 6 da relação "instanciação/envolvimento" selecionado. Somente os cubos que correspondem a este passo (111, $211 \mathrm{e}$ 222) estão visíveis.
Figura 60. Aspecto da interface de 10cubes, versão alpha-6, com o passo 6 da relação "instanciação/envolvimento", o cubo/classe 22l, e a modalidade "ícone" selecionados.
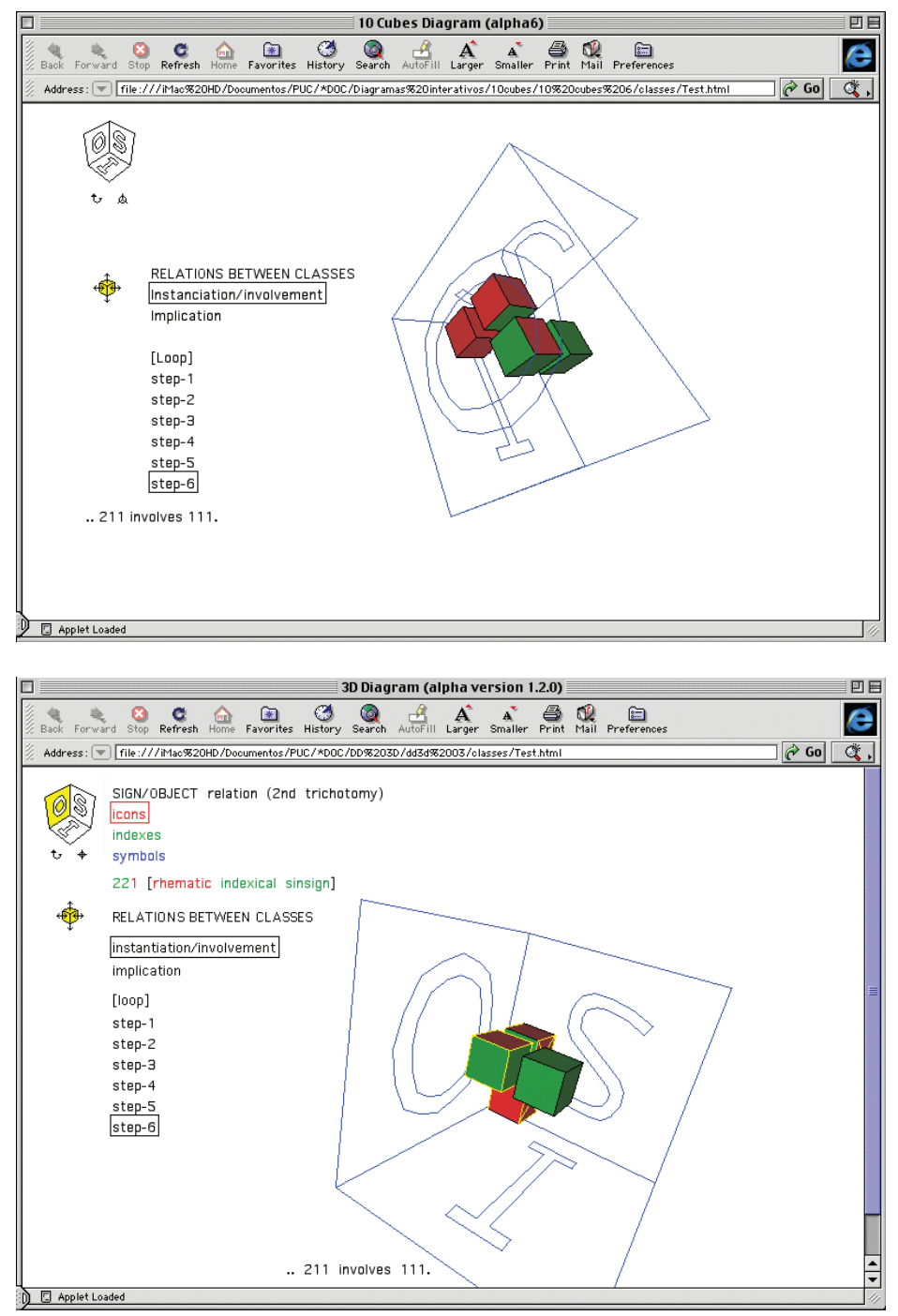

A partir da versão beta-1, foi acrescentado um recurso de ajuda ao usuário, que consiste em um botão help e uma página em html com créditos e informações básicas sobre como utilizar o diagrama (Figura 61).

A página de ajuda About 10cubes (Figura 62) apresenta ao usuário os recursos oferecidos pelo diagrama. Ela consiste em uma lista de ações e seus efeitos, precedida de pequenas ilustrações informativas (ícones, no jargão da informática) relativas a estas ações. Estas ilustrações traduzem visualmente o conteúdo das informações verbais, para tornar o acesso a estas 
informações mais intuitivo e rápido. Duas destas ilustrações informativas são imagens em movimento (Figuras 63 e 64), recurso utilizado para demonstrar com maior clareza as ações em questão.
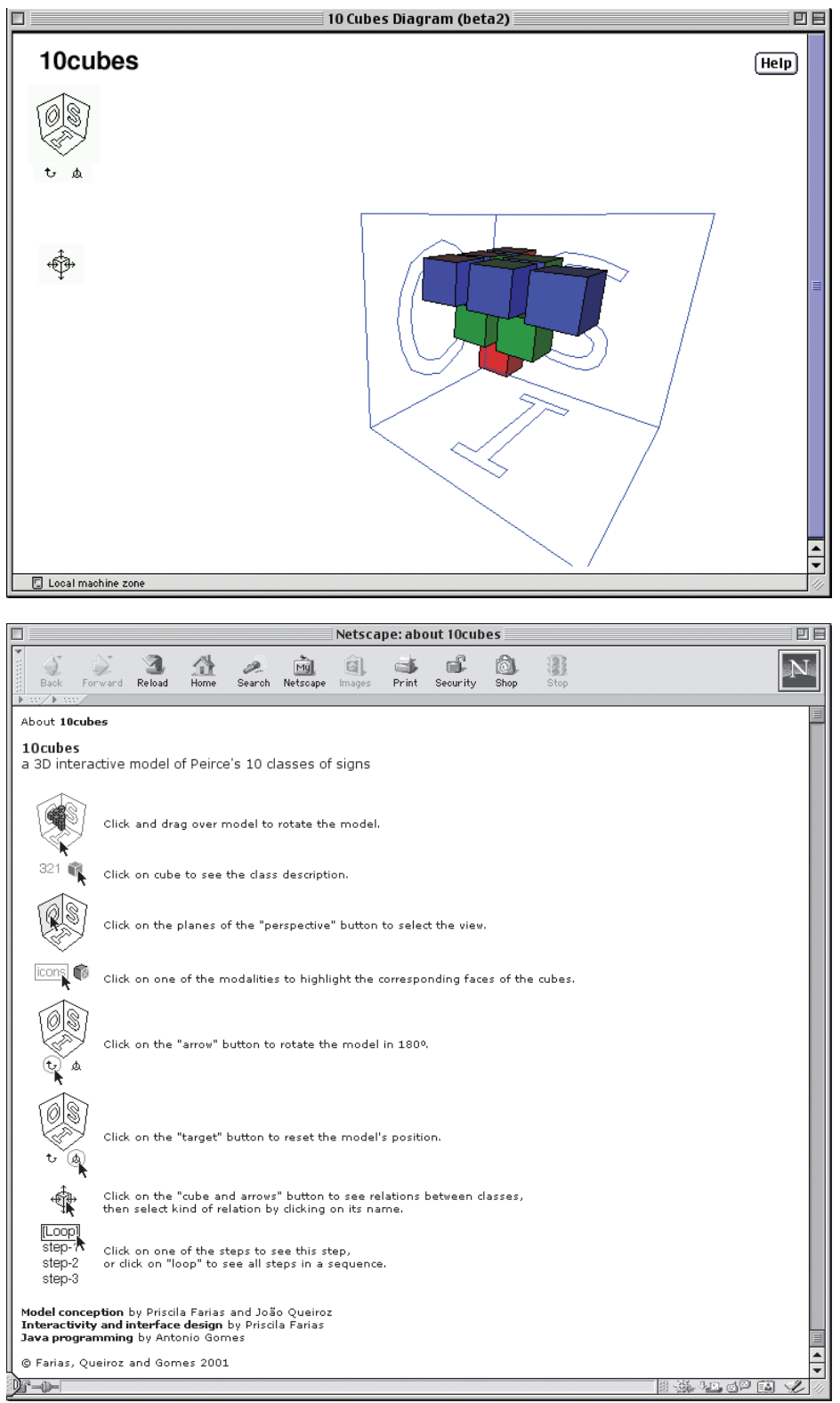

Figura 61. Aspecto da interface de 10cubes, versão beta-2, em que vemos, acima e à esquerda, o título do diagrama, e à direita o botão help.

Figura 62. About 10cubes, página de ajuda ao diagrama 10cubes. 
Figura 63. Sequência de imagens do gif animado "clicar-e-arrastar", na página de ajuda About 10cubes.
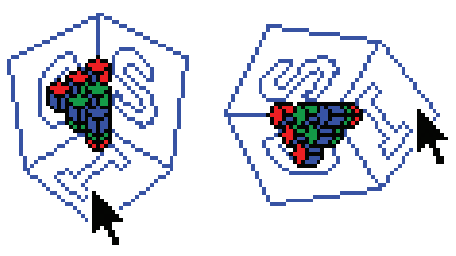

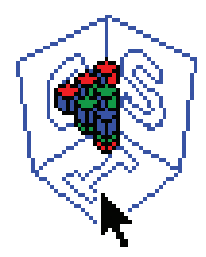

\begin{tabular}{llll}
\hline [Loopl & [Loop] & [Loop] & [Loop \\
step- & Step-1 & step-1 & step- \\
step-2 & step-2 & step-2 & step-2 \\
step-3 & step-3 & step-3r & step-3
\end{tabular}

Figura 64. Sequência de imagens do gif animado loop-ou-steps, na página de ajuda About 10cubes.

\section{Experimentação}

Conforme afirmamos, o objetivo de 10cubes foi modelar de forma dinâmica as relações entre as dez classes de signos, ao incorporar interatividade e modificação temporal utilizando recursos informáticos. O projeto inicial previa os seguintes recursos:

(i) visualização das relações entre tricotomias que formam as classes (Figuras 46 e 47),

(ii) visualização de subgrupos significativos de classes (por exemplo, ícones, índices e símbolos, Figuras 48, 49 e 50$)$, e

(iii) visualização de relações dinâmicas entre as classes (por exemplo, relações de instanciação e envolvimento, Figura 51).

O recurso adicional, não previsto no projeto inicial, de apresentar legendas para os cubos selecionados tornou mais eficiente a visualização das relações que formam as classes, prevista no item (i), ao informar, de forma mais clara, as modalidades tricotômicas que constituem cada cubo/classe. $\mathrm{O}$ fato de as legendas seguirem as mesmas regras para utilização de cores adotadas para colorir os cubos contribui para a percepção, do usuário, de correspondências entre as cores e as categorias cenopitagóricas (primeiridade, secundidade, terceiridade). O recurso de destacar os cubos selecionados, colorindo de amarelo suas arestas, permitia escolher um determinado cubo e depois girar o diagrama livremente para analisar, por exemplo, suas relações de proximidade e posição com os outros cubos.

A inclusão do botão $\mathrm{S} / \mathrm{O} / \mathrm{I}$ e das legendas relativas às tricotomias contribuiu para a realização do item (ii). De forma similar ao que ocorre com as legendas para as classes, as informações verbais fornecidas pelas legendas para as tricotomias fizeram com que a visualização de grupos especiais de cubos/ classes fosse mais clara e eficiente. Além disso, a possibilidade de selecionar estes grupos de cubos/classes, a partir das legendas, proporciona maior flexibilidade na visualização, uma vez que as faces dos cubos permanecem realçadas ao girarmos o 
diagrama. Também salientamos a relevância de regras visuais diferentes para a seleção de classe (cubo inteiro destacado por suas arestas) ou modalidade tricotômica (face do cubo destacada por suas diagonais), o que permite a visualização de informações "cruzadas" sobre os cubos/classes (por exemplo, a posição dos sinsignos icônicos dentro do grupo de classes de signos icônicos).

Quanto ao item (iii), as duas sequências implementadas ("instanciação / envolvimento" e "implicação") mostram que é possível implementar a visualização de relações dinâmicas entre as classes em 10cubes de forma simples. Futuros desenvolvimentos deste diagrama poderiam incluir a implementação de outras sequências de relações entre classes, como aquelas indicadas em Merrell (1991: 17, Figura 29). Outro desenvolvimento interessante seria a implementação de um mecanismo que permita a criação de sequências de relações por parte do usuário.

Grande parte dos botões e recursos descritos nesta seção não estavam previstos no projeto original e foram acrescentados ao projeto de interface a partir da utilização de versões preliminares do diagrama. Embora nenhum tipo de teste de usabilidade tenha sido efetuado de forma sistemática, comentários feitos por usuários a partir da versão alpha-6 também foram considerados no refinamento do design de interface. Estes comentários motivaram a inclusão do mecanismo de ajuda descrito nos últimos parágrafos da seção anterior. Acreditamos que este mecanismo esteja de acordo com os requisitos para um sistema de ajuda eficiente elencados por especialistas em design de interface (RASKIN 2000: 174-177; CATO 2001: 265) e que a versão beta-2 de 10cubes seria avaliada positivamente caso submetida a testes controlados de usabilidade.

\section{II.3.5. 3N3: explorando as estruturas e as relações entre as dez, 28 e 66 classes de signos}

$3 N 3$ é um software projetado para construir diagramas triangulares para diferentes classificações de signos - divisões em 10, 28, 66 classes, ou qualquer outro número de classes compatível com o modelo peirceano. ${ }^{45}$ Desenvolvido em Java, ele teve como objetivos principais (i) facilitar a análise de signos de acordo com os princípios diagramáticos das categorias, tricotomias e classes propostos por Peirce, (ii) possibilitar comparações de estruturas sígnicas semelhantes (por exemplo, legisignos icônicos) no contexto de diferentes classificações, e (iii) auxiliar na consideração de diferentes hipóteses, elaconstrução deste software foram expostos anteriormente em Farias e Queiroz (2000b, 2000c e 2001), em que nos referimos ao projeto para este desenvolvimento como "Diagramas Triangulares". Para uma apresentação das bases teóricas para as diferentes classificações, consultar o Capítulo I.1. 
boradas pelo próprio Peirce e por alguns de seus comentadores (em particular, WEISS; BURKS 1945; SANDERS 1970; LIEB 1977; MARTY 1990; MARÓSTICA 1992 e MÜLLER 1994), sobre as classificações baseadas em mais de três tricotomias - as divisões em 28 e 66 classes.

O projeto, que se concretizou com a implementação deste software, teve início com a análise de dois diagramas elaborados por Peirce para dez classes de signos (MS 540: 17, CP 2.264, EP2: 289-99, Figura 16, e L463: 132-146, CP 8.376, EP2: 483 491, Figura 23). Em Farias e Queiroz (2000c, 2001a e 2014), demonstramos que estes dois diagramas foram construídos com base nos mesmos princípios diagramáticos e sugerimos que estes princípios poderiam ser aplicados na construção de diagramas para qualquer conjunto n-tricotômico de classes baseado no modelo triádico do signo peirceano. A implementação destes princípios diagramáticos é o principal recurso do software $3 \mathrm{~N} 3$, que possui ainda outros mecanismos interativos. Uma ferramenta para construir estes diagramas teve implicações importantes, não somente para a compreensão da estrutura das classes e das classificações, mas também para a discussão sobre a ordem de determinação das tricotomias nas classificações em 28 e 66 classes.

Apresentamos a seguir as questões que levaram à elaboração de 3N3, sua fase de desenvolvimento, alguns experimentos e seus resultados.

\section{Conceitualização}

A primeira e mais conhecida das classificações, baseada em apenas uma tricotomia, divide os signos em ícones, índices e símbolos. É razoavelmente bem conhecida sua divisão em 10 classes, baseada em três tricotomias. Menos conhecidas, as divisões em 28 e 66 classes aparecem em diversos manuscritos e rascunhos de cartas escritas por Peirce para Lady Welby, em dezembro de 1908 (EP 2: 478-91; LIEB 1977: 80-85). Estas divisões baseiam-se, respectivamente, em seis e dez tricotomias. Embora diversos especialistas (como HOUSER 1992:

Efetuamos uma pesquisa bastante rigorosa entre os manuscritos de Peirce, no Peirce Edition Project (IUPUI), mas não podemos descartar a possibilidade de que algum diagrama para este tipo de classificação esteja perdido entre os documentos não publicados. 501-502; MÜLLER 1994: 135) concordem quanto à relevância destas classificações para a compreensão da semiótica peirceana, elas nunca receberam, por parte do próprio autor, o tratamento sistemático dado às dez classes. Conforme vimos em II.1, Peirce também desenhou vários diagramas para dez classes de signos (Figuras 15, 22, e 25), mas aparentemente ${ }^{46}$ nunca fez o mesmo para suas divisões em 28 e 66 classes. Esta 
foi a principal motivação para as investigações que levaram ao diagrama descrito nesta seção.

A fase de conceitualização de 3N3 iniciou-se através da análise e comparação de dois diagramas para as dez classes de signos (o "diagrama do Syllabus", Figura 16; e "o diagrama de Welby", Figura 23). O primeiro, conforme vimos em II.1.1, aparece no contexto de sua apresentação mais completa das dez classes de signos e é, sem dúvida, o mais conhecido dos dois. O segundo aparece em uma série de rascunhos de cartas para Lady Welby, e aparentemente não se refere às mesmas dez classes. ${ }^{47}$ Se negligenciarmos, por um momento, as diferenças entre as classes de signos presentes nos dois diagramas, poderemos apreciar suas similaridades estruturais. Em primeiro lugar, podemos notar que os dois diagramas possuem silhuetas muito parecidas, que podem ser descritas como formas triangulares equiláteras apoiadas em um de seus vértices. Estas silhuetas são formadas por células quadradas no diagrama do "Syllabus" e por células triangulares no diagrama de Welby. Em relação ao arranjo das classes, notamos que os dois diagramas possuem a mesma estrutura interna, organizada de forma espelhada por um eixo vertical no centro do diagrama. O espelhamento acontece de forma que as classes localizadas sobre este eixo (321 e 222) permanecem no mesmo lugar, enquanto as outras (por exemplo, 111 e 333) invertem suas posições. Estes dois pontos ficam mais claros ao compararmos as versões simplificadas dos dois diagramas, apresentadas nas Figuras 65 e 66.

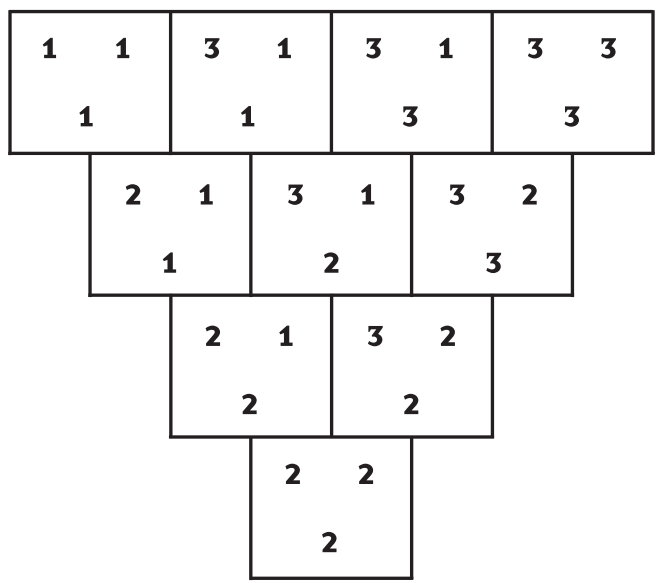

Figura 65. Syllabus-S: versão simplificada do diagrama para dez classes desenhado por Peirce em seu "Syllabus" de 1903 (MS 540: 17, EP 2: 296, Figura 16).
Conforme discutimos em II.I parece haver uma diferença na ordem de determinação das classes que aparecem nos dois diagramas. No diagrama do "Syllabus" ela é, explicitamente (EP2: 291), (i) signo em si mesmo, (ii) relação do signo com seu objeto, e (iii) relação do signo com seu interpretante. No diagrama de Welby ela parece ser, implicitamente, (i) natureza do objeto, (ii) signo em si mesmo, e (iii) natureza do interpretante.

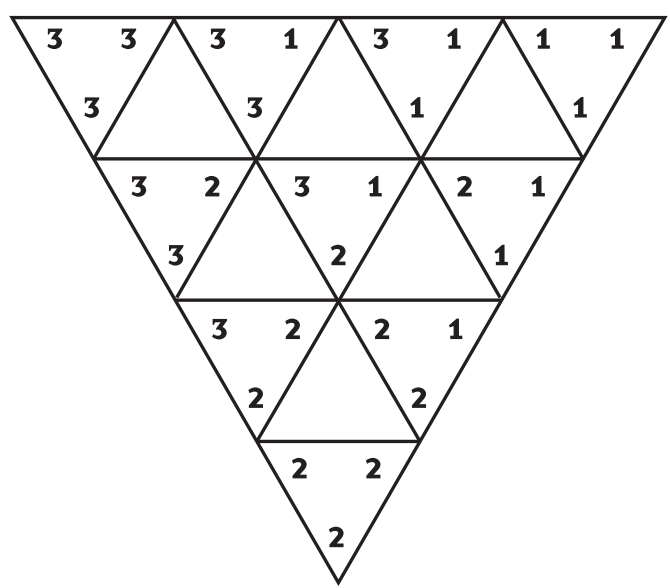

Figura 66. Welby-S: versão simplificada do diagrama para dez classes desenhado por Peirce em rascunho de carta para Lady Welby (L463:146, EP 2: 491, Figura 22). 
notação (11l para qualisigno 211 para sinsigno icônico, 321 para legisigno indexical remático etc.), já discutida na primeira parte deste livro, aparece em alguns manuscritos de Peirce (em especial MS 799:4), e é adotada por diversos especialistas (WEISS; BURKS 1945: 386; SANDERS 1970: 7; DELEDALLE; RÉTHORÉ 1979: 82; JAPPY 1984: 1; MERRELL 1991: 1, entre outros).

Conforme discutimos em II.1.2, um diagrama muito similar a Welby-S foi desenhado pelo próprio Peirce e pode ser encontrado em L463: 155 (Figura 25).

Esta estratégia foi inspirada no tratamento que Shea Zellweger dedica à lógica triádica de Peirce em Zellweger (1991).

$O$ valor de $a+b+c=3$ não deve ser confundido com a variação de $a, b, e c$ entre $\{0,1,2,3\}$. Neste exemplo, o valor de $a+b+c$ é igual a 3 porque estamos trabalhando com as três tricotomias que formam as dez classes. Conforme veremos a seguir, este valor deverá variar de acordo com o número de tricotomias envolvidas em uma determinada classificação.

52 Se dois dos elementos do tripleto $(a, b, c)$ são iguais a zero, e a soma destes elementos deve ter um valor constante, então um dos valores de $a, b$ ou cé igual ao valor de $a+b+c$ Isso significa que nos tripletos "extremos" ou $a=a+b+c$, ou $b=$ $a+b+c$, ou $c=a+b+c$.

No diagrama do "Syllabus" simplificado (Syllabus-S, Figura 65), a notação para as classes, que é verbal no diagrama original (Figura 16), foi substituída por uma notação numérica, ${ }^{48}$ disposta de forma similar à que aparece no diagrama para Welby (Figura 23). Além disso, a numeração em algarismos romanos, assim como a variação nas espessuras das divisões entre as células, foi suprimida. No diagrama de Welby simplificado (Welby-S, Figura 66), os triângulos com vértice para baixo que estavam "em branco" no diagrama original (Figura 22) foram suprimidos. ${ }^{49}$

Para generalizar as questões estruturais e mostrar que os dois diagramas seguem os mesmos princípios diagramáticos, é preciso compreender o posicionamento das classes nestes diagramas, em termos de coordenadas triangulares, ${ }^{50}$ em que cada classe é representada por um tripleto $(a, b, c)$. Para cada tripleto, os valores de $a, b$, e $c$ são números inteiros variando de 0 a 3 (correspondendo à quantidade de algarismos 1, 2 e 3 que compõem a notação numérica para cada classe), sendo que $a+b+c=3 .{ }^{51}$ Existem apenas dez tripletos que atendem a estas exigências. São eles: $(3,0,0),(2,1,0),(1,2,0),(0,3,0),(0,2,1)$, $(0,1,2),(0,0,3),(1,0,2),(2,0,1)$, e $(1,1,1)$.

Estes dez tripletos podem ser arranjados de acordo com coordenadas triangulares, conforme podemos acompanhar nas Figuras 67, 68 e 69. Para construir estas coordenadas, desenhamos um triângulo equilátero e posicionamos os tripletos extremos, isto é, aqueles em que dois de seus elementos são iguais a zero, ${ }^{52}$ em seus vértices (Figura 67). A seguir, os tripletos intermediários, isto é, aqueles em que os valores de $a, b$ e $c$ correspondem a sequências em que um dos elementos permanece igual a zero e os outros dois assumem valores do tipo $(n+1$, n-1), são posicionados entre estes vértices (Figura 68). Por fim, os pontos que correspondem aos tripletos "intermediários" são ligados por retas paralelas aos lados do triângulo, ao longo das quais são dispostos os tripletos "centrais" (Figura 69).

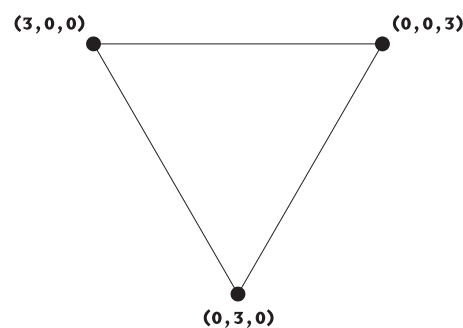

Figura 67. Construindo coordenadas triangulares para dez classes. Passo 1: posicionando os tripletos extremos $(3,0$, $0),(0,3,0)$ e $(0,0,3)$ nos vértices de um triângulo equilátero.

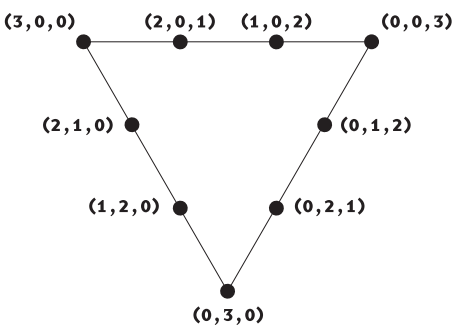

Figura 68. Construindo coordenadas triangulares para dez classes. Passo 2: posicionando os tripletos intermediários $(2,1$, $0),(1,2,0),(0,2,1),(0,1,2),(1,0,2)$ e $(2,0,1)$ entre os vértices extremos das coordenadas triangulares iniciadas no passo 1. 
O que obtemos na Figura 69 é um padrão de dez vértices que, conforme veremos, corresponde à estrutura interna dos dois diagramas para dez classes desenhados por Peirce (Figuras 20 e 25). Se considerarmos que o elemento a dos tripletos corresponde à quantidade de algarismos "1", o elemento $b$ à quantidade de algarismos " 2 ", o elemento $c$ à quantidade de algarismos " 3 " que formam a notação numérica para cada classe e desenharmos quadrados ao redor dos vértices, obteremos um diagrama idêntico ao Syllabus-S (comparar Figura 65 e Figura 70). Por outro lado, se invertermos as correspondências de $a$ e $c$, isto é, se considerarmos que o elemento $a$ dos tripletos corresponde à quantidade de algarismos " 3 ", o elemento $b$ à quantidade de algarismos " 2 ", o elemento $c$ à quantidade de algarismos " 1 ", e desenharmos triângulos ao redor dos vértices, obteremos um diagrama idêntico a Welby-S (comparar Figura 66 e Figura 71).

É possível utilizar coordenadas triangulares para determinar o arranjo de qualquer conjunto cuja quantidade de elementos seja igual a um número triangular. Define-se um número triangular como um inteiro que segue a fórmula $n(n+1) / 2$, onde $n$ é um número natural. Aplicada aos inteiros positivos, esta fórmula fornece a sequência $\{1,3,6,10$, $15,21,28, \ldots\}$. A fórmula proposta por Weiss e Burks (1945: 387) para calcular o número de classes de signos válidas no sistema peirceano, a partir de um certo número de tricotomias, $(n+1)(n+2) / 2$, pode ser considerada um caso especial da fórmula anterior, fornecendo números triangulares a partir de 3. Uma vez que esta fórmula sempre fornecerá números triangulares, pode-se dizer que é possível utilizar coordenadas triangulares para construir diagramas para qualquer número de classes de signos. Assim, o mesmo procedimento usado para reconstruir os diagramas Syllabus-S e Welby-S pode ser utilizado para construir diagramas para qualquer classificação de signos, incluindo as divisões em 28 e 66 classes, conforme veremos a seguir.

Para construir um diagrama baseado em coordenadas triangulares para as 28 classes, devemos criar um padrão de vértices onde localizamos os 28 tripletos da forma $(a, b, c)$ que correspondem a estas classes. Uma vez que a divisão em 28 classes está baseada em seis tricotomias, os elementos $a, b$ e $c$ destes tripletos devem variar entre $\{0,1,2,3,4,5,6\},{ }^{53}$ respeitando a regra $a+b+c=6$. Da mesma forma como procedemos para determinar o arranjo de dez vértices (Figuras 67, 68 e 69), começamos por posicionar os tripletos extremos $(6,0,0),(0,6,0)$ e $(0,0,6)$

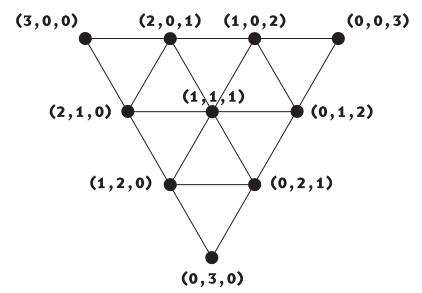

Figura 69. Construindo coordenadas triangulares para dez classes. Passo 3 : posicionando o tripleto central $(1,1,1)$ no cruzamento das retas que ligam os pontos $(2,1,0)$ e $(1,2,0),(0,2,1)$ e $(0,1$, $2),(1,0,2)$ e $(2,0,1)$.

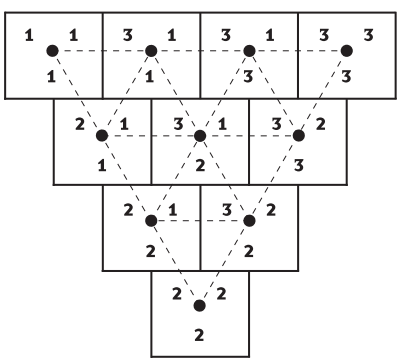

Figura 70. Syllabus-S reconstruído a partir das coordenadas triangulares para dez classes (comparar com Figura 65).

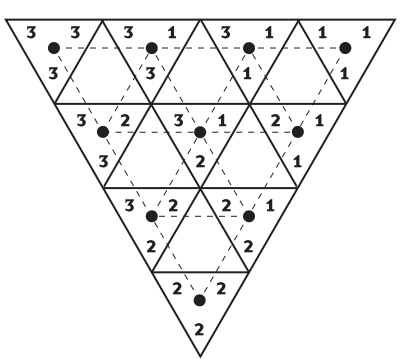

Figura 71. Welby-S reconstruído a partir das coordenadas triangulares para dez classes (comparar com Figura 66).

53 Relembrando, isso correspondeà quantidade de algarismos "1", "2" e "3" que compõem a notação numérica para as classes. Uma vez que estamos trabalhando com seis tricotomias, a quantidade de algarismos "1", "2" e " 3 " que compõe cada uma das classes deverá variar entre 0 e 6. 
54 Isso significa que, ao longo dos lados do triângulo teremos as seguintes sequências:

$(6,0,0),(5,1,0),(4,2,0),(3,3,0),(2$,

$4,0),(1,5,0),(0,6,0)$

$(0,6,0),(0,5,1),(0,4,2),(0,3,3)$,

$(0,2,4),(0,1,5),(0,0,6)$; e

$(0,0,6),(1,0,5),(2,0,4),(3,0,3)$,

$(4,0,2),(5,0,1),(6,0,0)$.

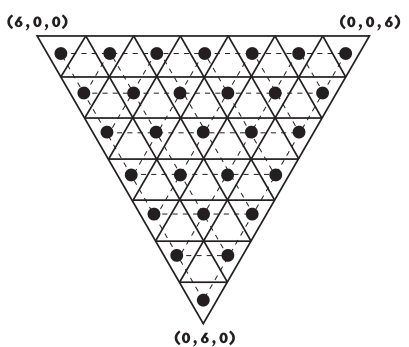

Figura 72. Diagrama para 28 classes construído ao redor de um padrão de 28 vértices dispostos de acordo com coordenadas triangulares.

Figura 73. Diagrama triangular para 28 classes, com notação numérica. Os pontos indicam as células ocupadas por classes no diagrama de Welby (Figura 22). nos vértices de um triângulo equilátero, e os quinze tripletos intermediários ao longo dos lados correspondentes deste mesmo triângulo. ${ }^{54}$ Ligando os pontos marcados pelos tripletos intermediários com retas paralelas aos lados do triângulo, obtemos um padrão de 28 vértices, ao redor dos quais podemos construir células triangulares para abrigar as 28 classes (Figura 72).

Podemos agora "traduzir" os tripletos nas sequências de algarismos 1, 2 e 3 que formam a notação numérica para as classes. Se adotamos as mesmas correspondências utilizadas para reconstruir o diagrama Welby-S, obtemos um diagrama bastante similar ao diagrama de Welby original (comparar Figura 22 e Figura 73). Esta é uma indicação de que, se Peirce tivesse desenhado diagramas para as 28 classes, ele provavelmente usaria um método similar ao que estamos empregando aqui. $\mathrm{O}$ mesmo método pode ser utilizado para construir um diagrama equivalente para as 66 classes de signos (Figura 74).

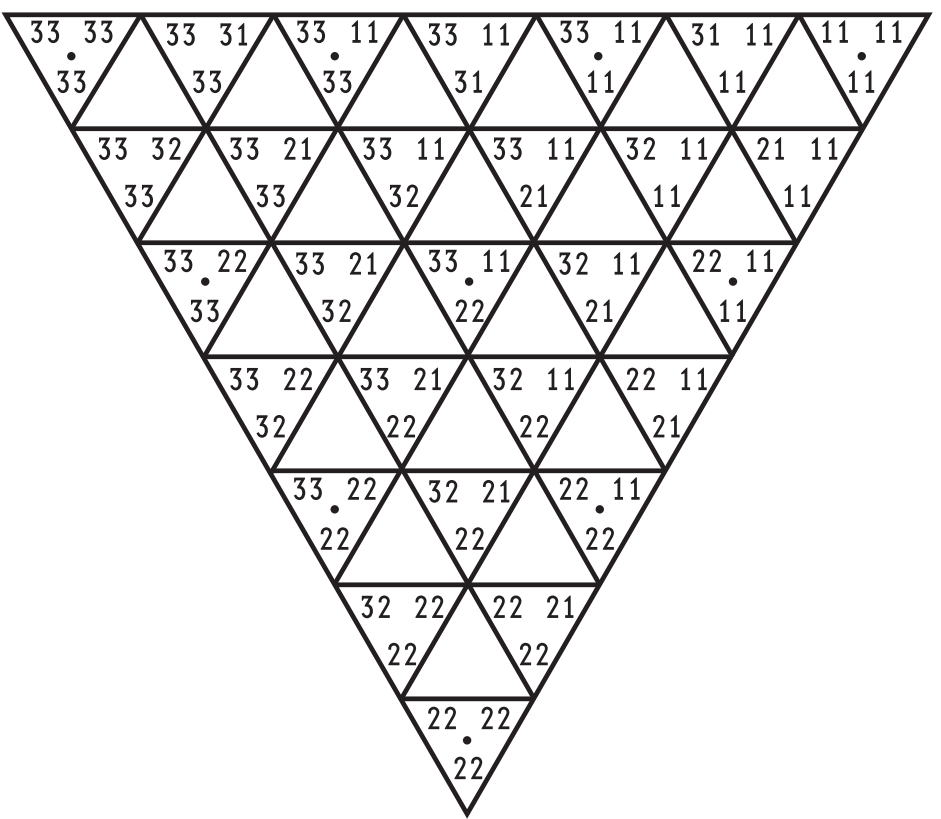

Uma das vantagens deste procedimento está relacionada à capacidade de construção de diagramas equivalentes para qualquer classificação de signos, consistente com o sistema peirceano. Isto, conforme afirmamos em outras ocasiões (FARIAS; QUEIROZ 2000b, 2000c, 2001, 2003, 2014), permite analisar e comparar as diferentes - e muitas vezes conflitantes - hipóteses sobre as divisões dos signos em 28 e 66 classes. Nos artigos mencionados, apresentamos alguns exemplos destas análises e 
comparações, que eventualmente forneceram as bases para o design do 3n3, um software que implementa a construção de "diagramas triangulares".

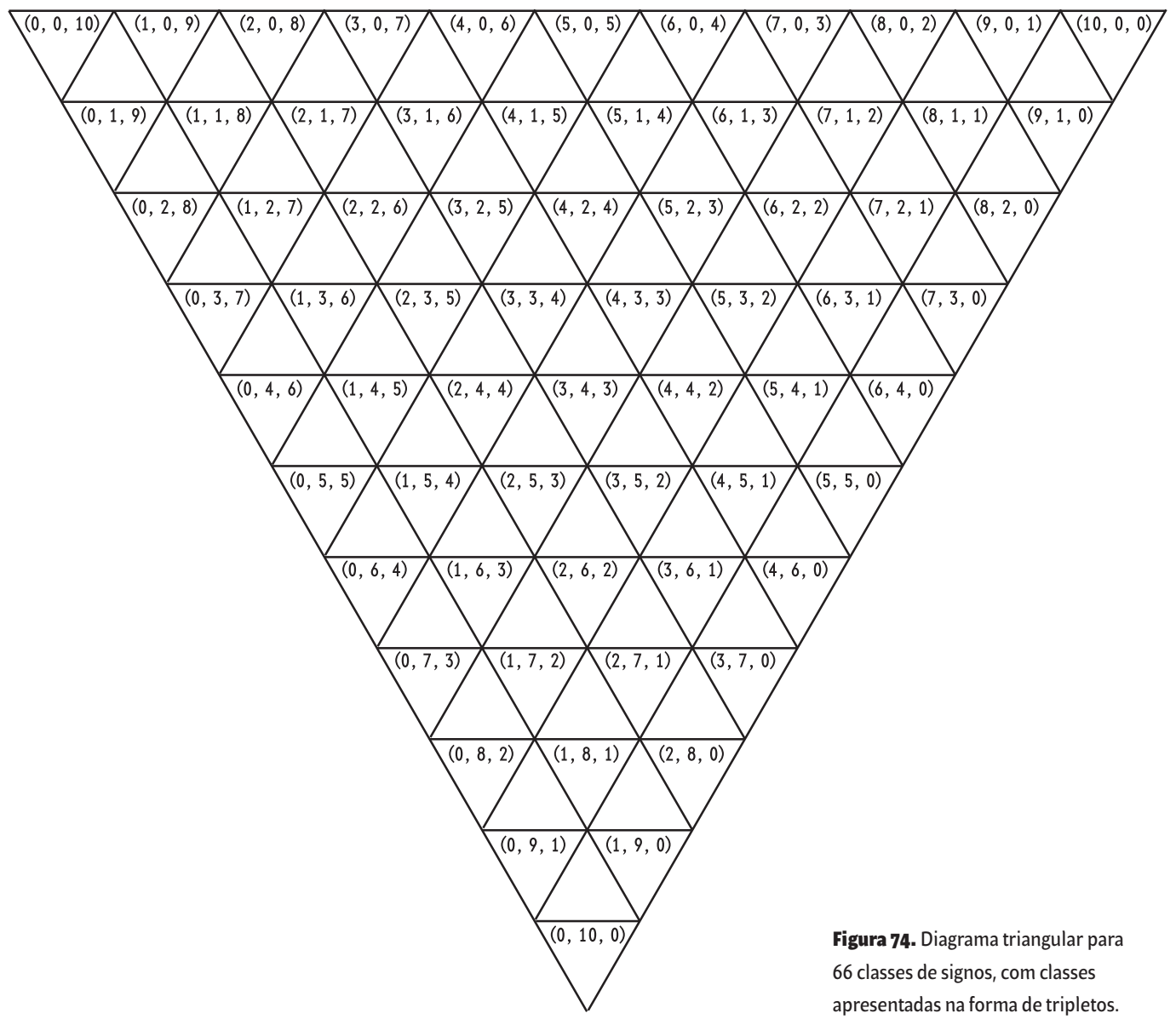

\section{Desenvolvimento}

Uma das maiores dificuldades para construção manual dos diagramas triangulares é determinar as coordenadas triangulares e cuidar para que os tripletos sejam expressos corretamente e dispostos nas posições adequadas. A análise e comparação de hipóteses, por sua vez, requer uma tradução destes tripletos em notação numérica e também, muitas vezes, em uma descrição verbal. 3N3 foi concebido para facilitar a construção e análise destes diagramas, automatizando o processo de geração e providenciando uma forma rápida e simples de análise de seus componentes. A primeira versão de 3N3 possuía apenas o recurso de gerar diagramas equivalentes para um certo 
Figura 75. Aspecto da versão alpha-1 de $3 N 3$, com o menu de seleção do número de tricotomias ativado.

Figura 76. Aspecto da versão alpha-1 de $3 N 3$, com algumas células de um diagrama para 28 classes selecionadas. número de classes, de acordo com uma quantidade de tricotomias variando entre 3 e 10 (Figura 75). As classes apareciam descritas como tripletos e era possível selecionar um ou mais elementos do diagrama (Figura 76).
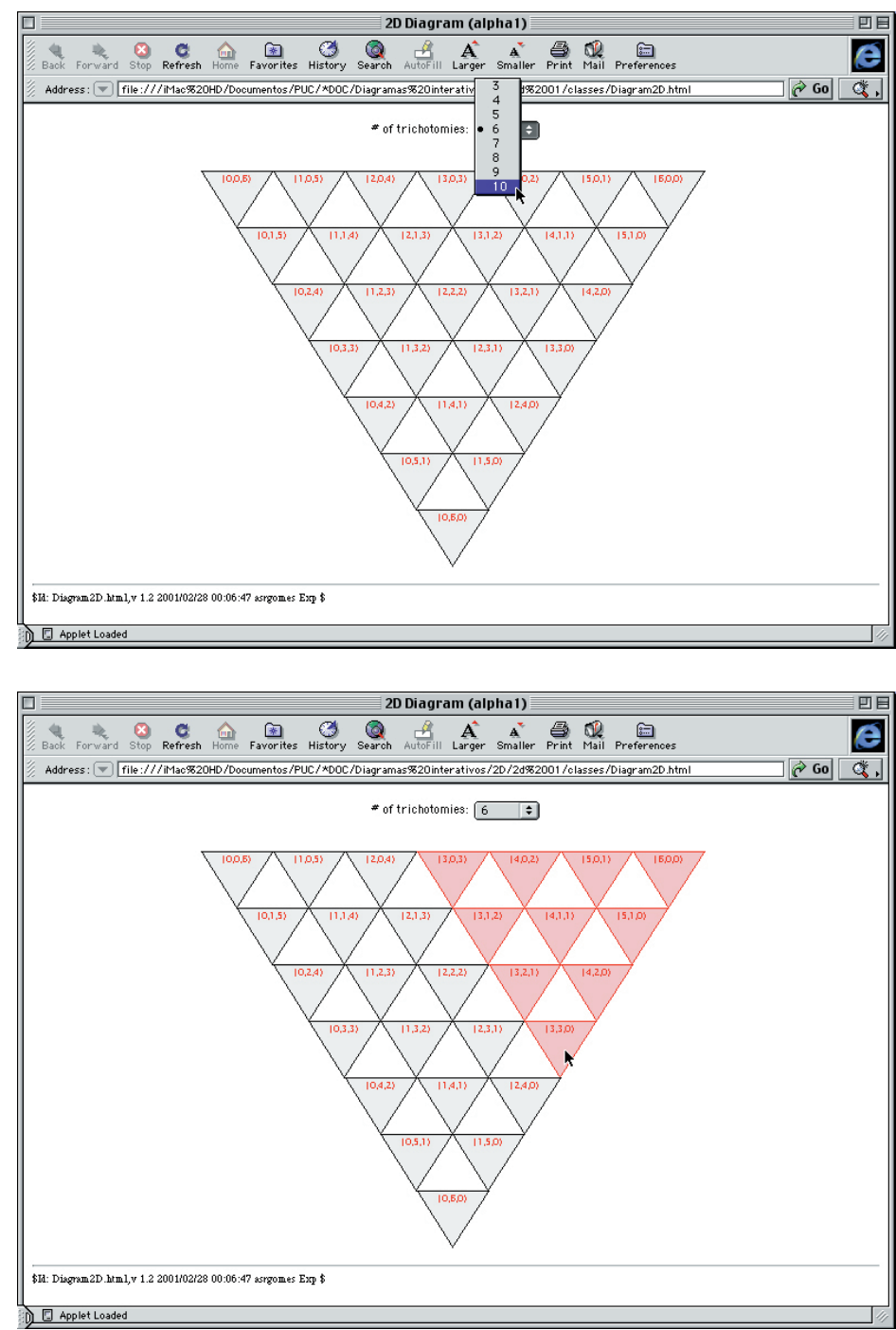

A partir deste desenvolvimento, foram estabelecidas diversas especificações para a interface e funcionamento do programa, que começaram a ser implementadas nas versões subsequentes do software. As principais inovações em relação ao esboço original foram a criação de um campo que exibia a notação numérica para as classes selecionadas e uma tabela que fornecia a descrição verbal para estas classes (Figura 77). 


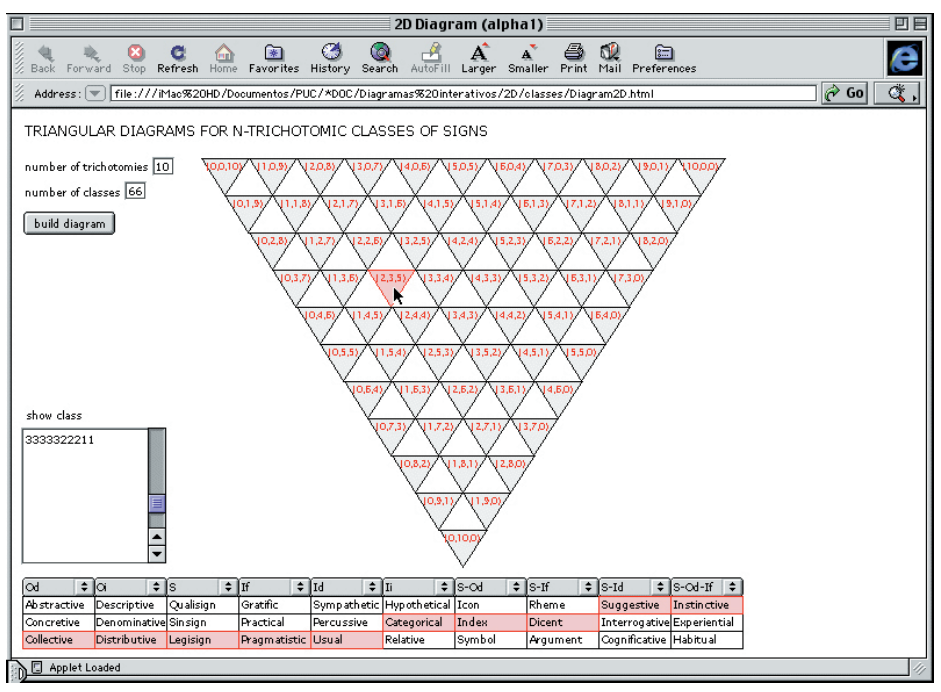

Desenvolvimento - interface de entrada

A partir da versão alpha-2, a interface de entrada de 3N3 (Figura 78) passou a ter, como elementos principais, dois campos para inserção de valores numéricos, intitulados number of classes ("número de classes") e number of trichotomies ("número de tricotomias"), e um botão intitulado build diagram ("construir diagrama"). 3N3 utiliza os valores inseridos no campo number of trichotomies como $n$ para calcular e mostrar o valor $c$ de classes no campo number of classes, de acordo com a fórmula $c=(n+1)(n+2) / 2$ e vice-versa. Com um destes campos preenchidos, é suficiente clicar no botão build diagram para ver o software construir um diagrama correspondente.

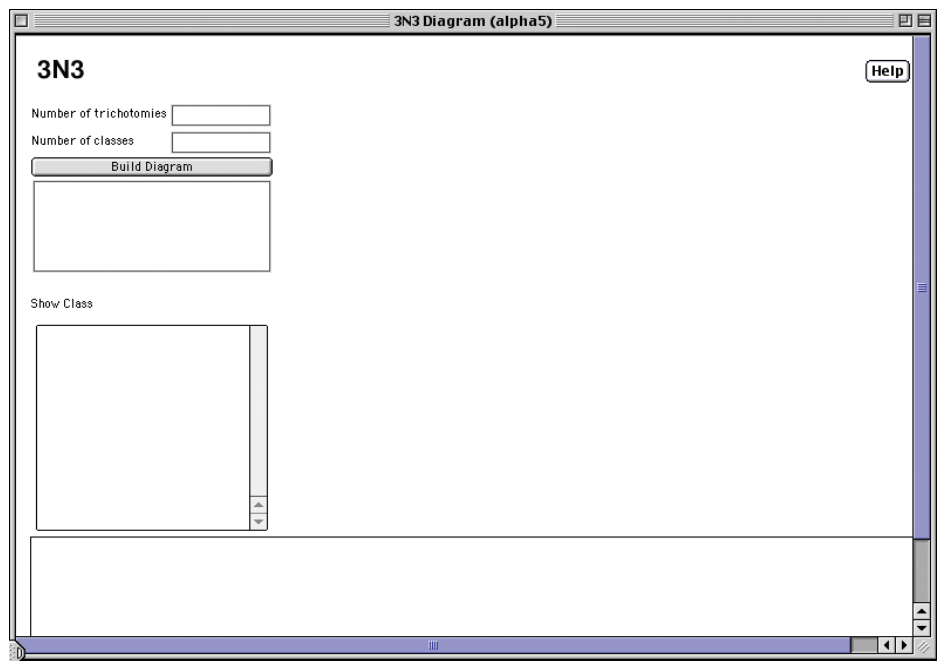

Figura 77. Aspecto do projeto de interface para $3 \mathrm{~N}_{3}$, com uma das células do diagrama selecionada, com a descrição verbal da classe destacada na tabela, e a notação numérica correspondente na lista "show class", acima dela.

Figura 78. A interface de entrada de $3 \mathrm{~N}_{3}$ na versão alpha-5.1. 


\section{N3}

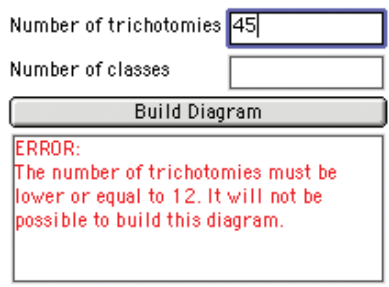

Figura 79. Mensagem de erro para número de tricotomias maior do que o limite estipulado, na versão alpha-5.1 de 3 N3.

\section{N3}

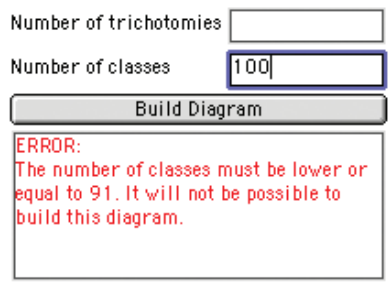

Figura 80. Mensagem de erro para número de classes maior do que o limite estipulado, na versão alpha-5.1 de 3 N3.

\section{N3}

Number of trichotomies 4

Number of classes

15

Build Diagram

WARNING:

Values not bestowed by Peirce

Scholarship. The number of classes must

be a positive integer that conforms to the

formula $(n+1)(n+2) / 2$. The closest

upper allowed value has been set.

Figura 81. Mensagem de alerta para número de classes que não obedece à fórmula $(n+1)(n+2) / 2$, na versão alpha-5.1 de 3 N3.
O número de classes e tricotomias foi limitado a duas casas decimais, podendo chegar a até doze tricotomias, ou 91 classes. Estes números não precisariam ser limitados, mas a falta de um limite aumentaria desnecessariamente a complexidade da implementação, principalmente no que diz respeito à construção dos diagramas e respectivas tabelas, como veremos. Os diagramas se tornariam ilegíveis, caso mantivessem o mesmo tamanho, ou precisariam crescer ilimitadamente, aumentando sua área em proporção ao número de classes em questão. As tabelas, por outro lado, se tornariam muito longas, crescendo em proporção ao número de tricotomias envolvidas.

Desenvolvimento - alertas

O número de tricotomias inserido no campo number of trichotomies deve ser um inteiro maior ou igual a 1 . O número de classes no campo number of classes, por sua vez, deve obedecer à fórmula $(n+1)(n+2) / 2$. Um campo foi criado logo abaixo do botão build diagram para mostrar mensagens de alerta a respeito dos valores inseridos nos campos number of trichotomies e number of classes. Se o usuário inserisse um número de tricotomias ou classes maior do que o limite aceito pelo programa (doze tricotomias, 91 classes), este campo exibiria uma mensagem de erro informando o valor deste limite (Figuras 79 e 80).

Caso o usuário inserisse no campo number of classes um valor que não obedecesse à fórmula $(n+1)(n+2) / 2$, o programa substituiria este número pelo mais próximo, e maior valor válido, e enviaria uma mensagem de alerta (Figura 81). Embora o software permitisse criar diagramas com diferentes número de classes e tricotomias, apenas alguns destes valores (1, 3, 6 e 10 para o número de tricotomias; 3, 10, 28 e 66 para o número de classes) são considerados válidos pelos especialistas na semiótica de Peirce. Se os valores inseridos fossem diferentes destes, o programa construiria o diagrama, mas enviaria uma mensagem de alerta (Figura 82).

\section{Construindo diagramas com $3 \mathrm{~N} 3$}

Ao clicar no botão build diagram, um diagrama triangular com o número de classes determinado no campo number of classes seria construído (a Figura 83 mostra um exemplo). As classes eram representadas nos diagramas por tripletos da forma $(a, b$, c) onde $a$ corresponderia ao número de algarismos $1, b$ ao número de algarismos 2, e $c$ ao número de algarismos 3 que constituía a notação numérica para cada classe. O tripleto "extremo", no qual a seria igual ao valor expresso no campo 
number of trichotomies, colocado no canto superior direito do diagrama; aquele onde $c$ é igual a este valor seria colocado no canto superior esquerdo, e aquele onde $b$ é igual a este valor seria colocado no canto inferior.

A organização dos tripletos, assim como a convenção para sua tradução na notação numérica, poderiam ser diferentes sem prejuízo para a coerência dos diagramas: as posições dos tripletos extremos superiores poderiam ser invertidas, assim como a convenção para a tradução dos elementos $a$ e $c$. A escolha dos parâmetros utilizados nesta versão do programa levou em consideração o fato de que o diagrama mais conhecido para as classificações de Peirce é o diagrama do "Syllabus" (Figura 16), e buscou tornar mais intuitiva a tradução dos tripletos em notação numérica. Para isso, a estrutura deste diagrama (classe 111 no canto superior direito, classe 333 no canto superior esquerdo) foi mantida, e, para o estabelecimento de correspondências entre os elementos dos tripletos e sua tradução em algarismos, foi seguida a ordem alfabética ( $\mathrm{a}=$ quantidade de $1 \mathrm{~s}, \mathrm{~b}=$ quantidade de $2 \mathrm{~s}, \mathrm{c}=$ quantidade de $3 \mathrm{~s}$ ).

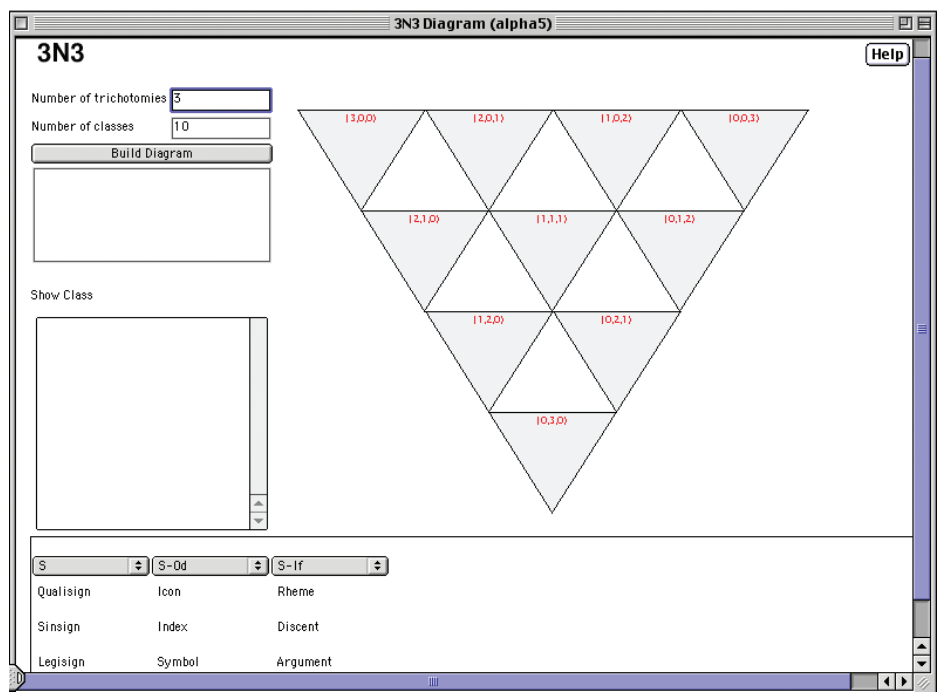

Tabelas de tricotomias

Além do diagrama, o programa construía uma tabela com as tricotomias envolvidas na classificação. Estas tabelas tinham a função de fornecer informação para a leitura dos tripletos em termos de descrições verbais para as classes de signos. Elas eram formadas por 4 linhas, em que, de cima para baixo, a primeira corresponderia ao nome da tricotomia, e as outras três

\section{N3}

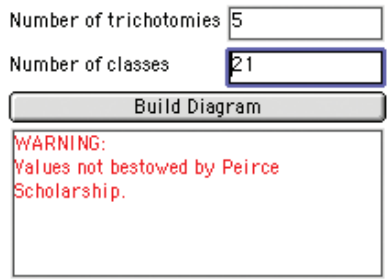

Figura 82. Mensagem de alerta para número de classes ou de tricotomias que não considerados válidos pelos especialistas, na versão alpha-5.1 de 3N3.

Figura 83. Diagrama triangular para dez classes de signos criado pela versão alpha-5.1 de 3 N3. 
Esta lista, com exceção do item "other (outro)" segue a sequência de tricotomias suas respectivas abreviaturas e modalidades discutida na Seção I.1.3.
Figura 84. Diagrama triangular para dez classes de signos criado pela versão alpha-5.1 de $3 N_{3}$, com o menu dropdown da última coluna da tabela ativado. às modalidades primeiridade ( $2^{\underline{a}}$ linha), secundidade ( $3^{\underline{a}}$ linha) e terceiridade ( $4^{\mathrm{a}}$ linha), de cada uma destas tricotomias. O número de colunas era sempre igual ao número de tricotomias determinado no campo number of trichotomies.

A primeira linha das tabelas era formada por uma sequência de menus drop-down (que se transformavam em listas quando clicávamos sobre eles, Figura 84), todos com as seguintes opções: ${ }^{55}$

$S$ ([natureza do] Signo);

Oi ([natureza do] Objeto Imediato);

Od ([natureza do] Objeto Dinâmico);

S-Od (relação do Signo com o Objeto Dinâmico);

Ii ([natureza do] Interpretante Imediato);

Id ([natureza do] Interpretante Dinâmico);

S-Id (relação do Signo com o Interpretante Dinâmico);

If ([natureza do] Interpretante Final);

S-If (relação do Signo com o Interpretante Final); e

S-Od-If (relação do Signo com o Objeto Dinâmico e Interpretante Final)

other (outro).

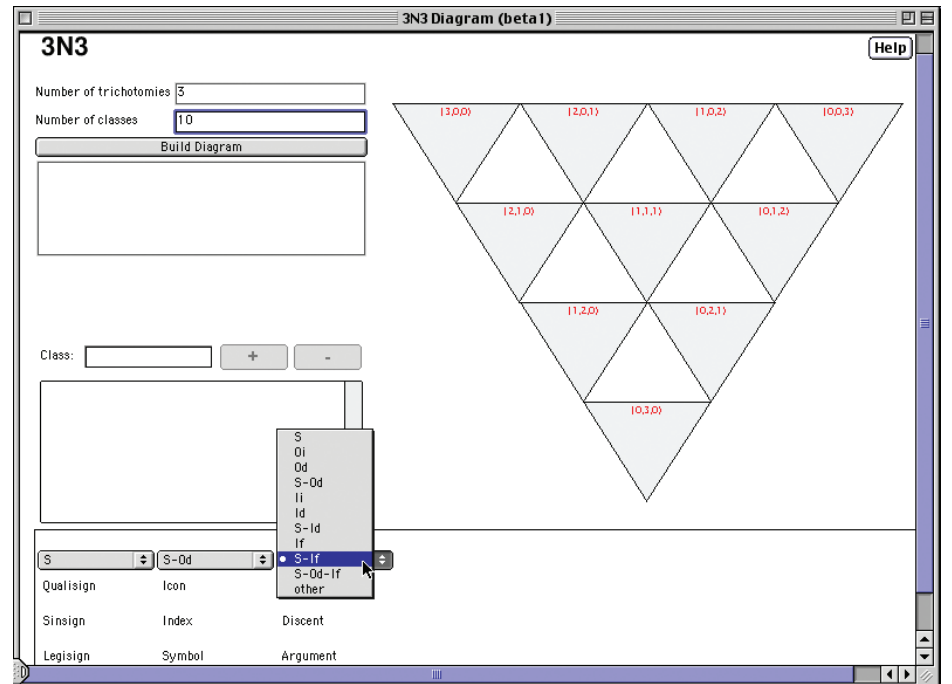

O projeto de interface previa que o significado das abreviaturas dos menus drop-down apareceria na forma de submenu ao lado de cada uma delas (Figura 85). Este recurso não pôde ser implementado devido a limitações correntes, na época, da linguagem Java, e as informações sobre o significado destas 
abreviaturas passaram a ser dadas na página de ajuda, como discutimos adiante.

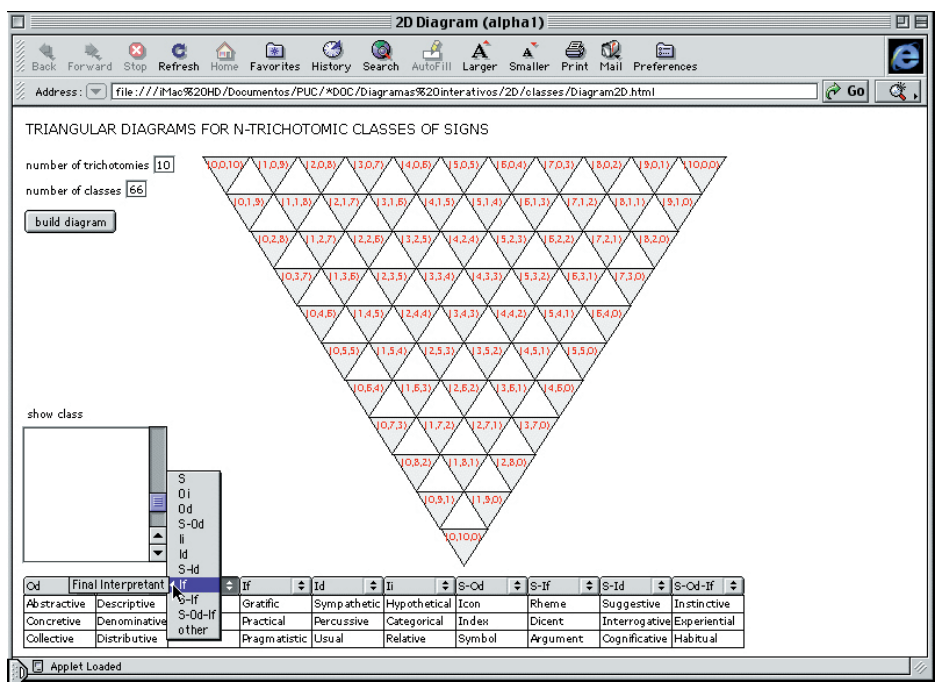

Por default, e com base no que foi discutido a respeito das tricotomias e classificações no Capítulo I.1., algumas combinações especiais de número de tricotomias/número de classes geravam sequências específicas de opções das listas dos menus drop-down. A combinação que corresponderia à divisão em dez classes gerava a sequência $(\mathrm{S}, \mathrm{S}$-Od, S-If) (Figura 84 ); a que corresponderia à divisão em 28, a sequência (Od, Oi, S, If, Id, Ii) (Figura 87); e aquela que corresponderia à divisão em 66 classes, a sequência $(S, O i$, Od, S-Od, Ii, Id, S-Id, If, S-If, S-Od-If) (Figura 87).

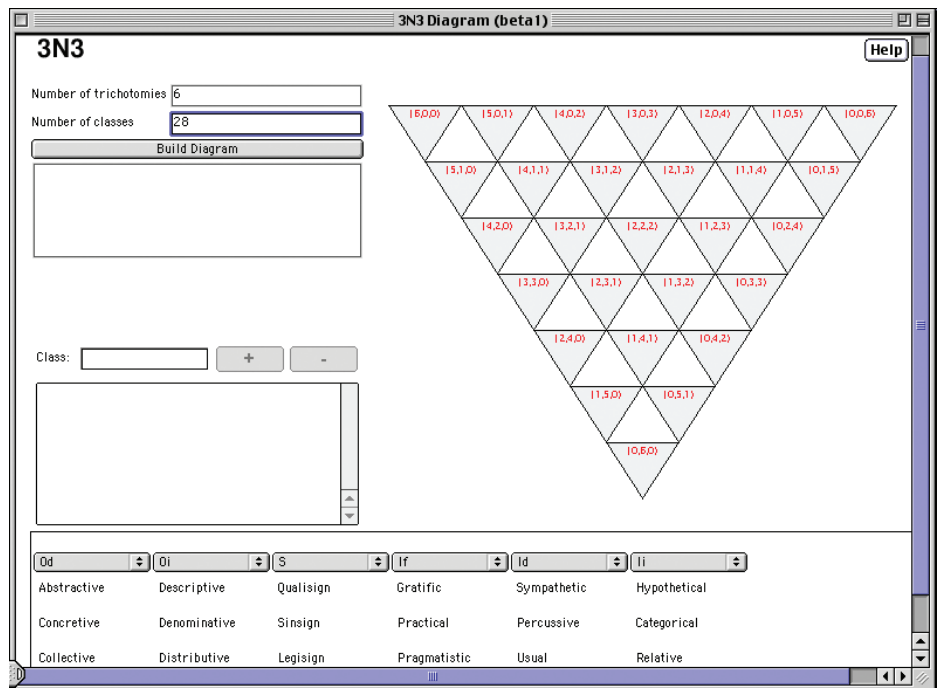

Figura 85. Aspecto do projeto de interface de $3 N 3$, simulando a ativação do recurso de submenus dentro dos menus drop-down.

Figura 86. Diagrama triangular para 28 classes de signos criado pela versão alpha-5.1 de $3 \mathrm{~N} 3$. 


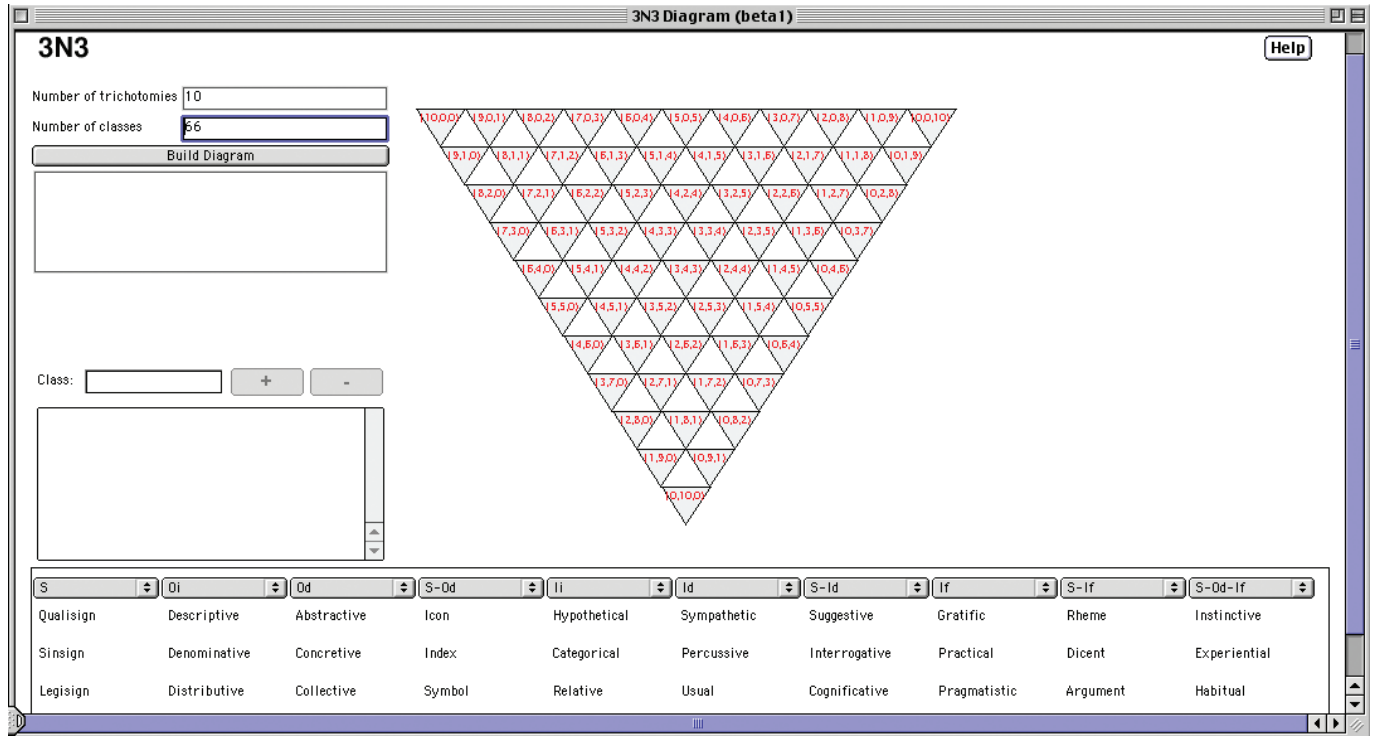

Figura 87. Diagrama triangular para 66 classes de signos criado pela versão alpha-5.1 de 3 N3.

No caso limite da tabela do diagrama para 91 classes/12 tricotomias, a opção "other" é repetida na $11^{\mathrm{a}}$ e na $12^{\mathrm{a}}$ coluna.
Para todas as outras combinações, a sequência de opções seguia a ordem dos itens do menu drop-down. ${ }^{56}$ Em qualquer caso, o usuário teria sempre a possibilidade de modificar estas sequências por meio da manipulação dos menus. O conteúdo das demais células da tabela seguia, com a exceção da opção other, a nomenclatura para as modalidades mais utilizadas pelos comentadores e discutida na Seção I.1.3:

\section{S: Qualisign, Sinsign, Legisign;}

Oi: Descriptive, Denominative, Distributive;

Od: Abstractive, Concretive, Collective;

S-Od: Icon, Index, Symbol;

Ii: Hypothetical, Categorical, Relative;

Id: Sympathetic, Percussive, Usual;

S-Id: Suggestive, Interrogative, Cognificative;

If: Gratific, Practical, Pragmatistic;

S-If: Rheme, Dicent, Argument;

S-Od-If: Instinctive, Experiential, Habitual.

A opção other permitia, ainda, que o usuário utilizasse nomenclaturas alternativas, ou mesmo que estabelecesse sua própria nomenclatura. Para isso, bastaria digitar nos campos apropriados a nomenclatura desejada e em seguida pressionar a tecla return para fixá-la na tabela. 
Tripletos, classes, listas e tabelas

Ao clicar em uma célula do diagrama poderíamos observar, na lista show class, a tradução do tripleto a que esta célula corresponde em uma sequência de algarismos 1,2 e 3 que descrevem esta classe "numericamente", de acordo com as categorias cenopitagóricas. Também poderíamos observar, destacadas em vermelho na tabela, uma sequência de células que correspondente à descrição verbal desta classe (Figura 88). Este procedimento era particularmente útil para revelar o significado de um tripleto em termos verbais ou numéricos.

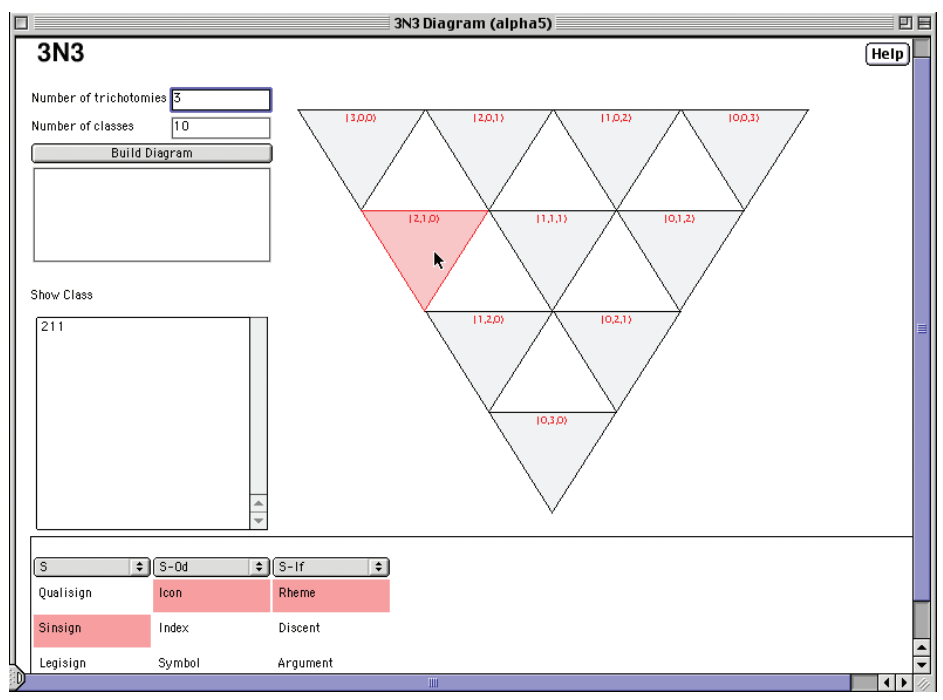

De modo similar, ao clicar em uma célula da tabela poderíamos observar, na lista show class a classe (ou o conjunto de classes) que possuía este elemento - uma modalidade em uma tricotomia, em uma certa posição, por exemplo, "ícones" na segunda tricotomia - em sua composição. No diagrama, as células com os tripletos correspondentes a estas classes são automaticamente realçadas. No restante da tabela, células que correspondem a modalidades necessariamente envolvidas pela modalidade selecionada (por exemplo, "remas", pois todos os ícones são remáticos) aparecerão em vermelho, e células que correspondem a modalidades que podem estar envolvidas mas que não fazem parte da composição de todas as classes que compõem o conjunto das classes com a modalidade selecionada (por exemplo, "qualisigno", "sinsigno" e "legisigno", uma vez que os ícones podem ser signos com estas naturezas) aparecem com o contorno em vermelho. As modalidades que não estão envolvidas, de nenhuma forma, permanecem em branco (Figura 89).
Figura 88. Diagrama triangular para dez classes de signos criado pela versão alpha-5.1 de $3 N 3$ com a célula que contém o tripleto $(2,1,0)$ selecionada. 
Figura 89. Diagrama triangular para dez classes de signos criado pela versão alpha-5.1 de 3N3 com a célula "icon" da tabela selecionada.
Figura 90. Diagrama triangular para 66 classes de signos criado na versão beta-1 de $3 N 3$, com as células "legisign", "index" e "rheme" da tabela selecionadas.

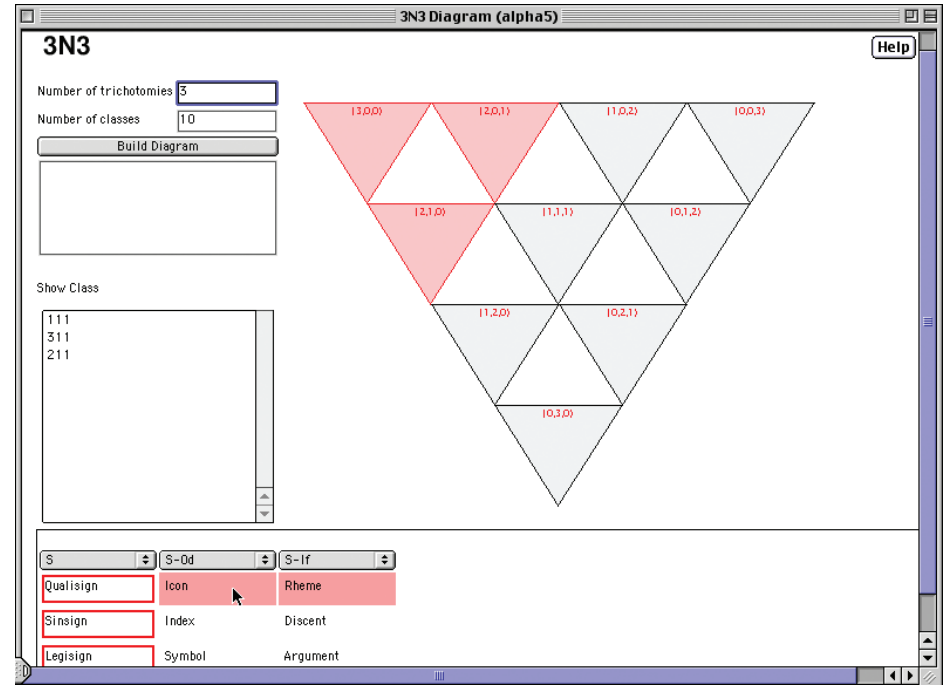

Este último procedimento é particularmente útil para identificar subgrupos especiais de classes dentro de uma classificação. Através deste recurso podemos, por exemplo, localizar com facilidade todos os ícones presentes em um diagrama triangular que tem a mesma estrutura do diagrama do "Syllabus" (Figura 89). Selecionando mais de uma célula da tabela podemos também relacionar diferentes classificações e identificar, por exemplo, quais são as classes que podem ser descritas como "legisignos indexicais remáticos" (321) dentro de um diagrama para 66 classes. Este recurso foi implementado na versão beta-1 do programa (Figura 90).

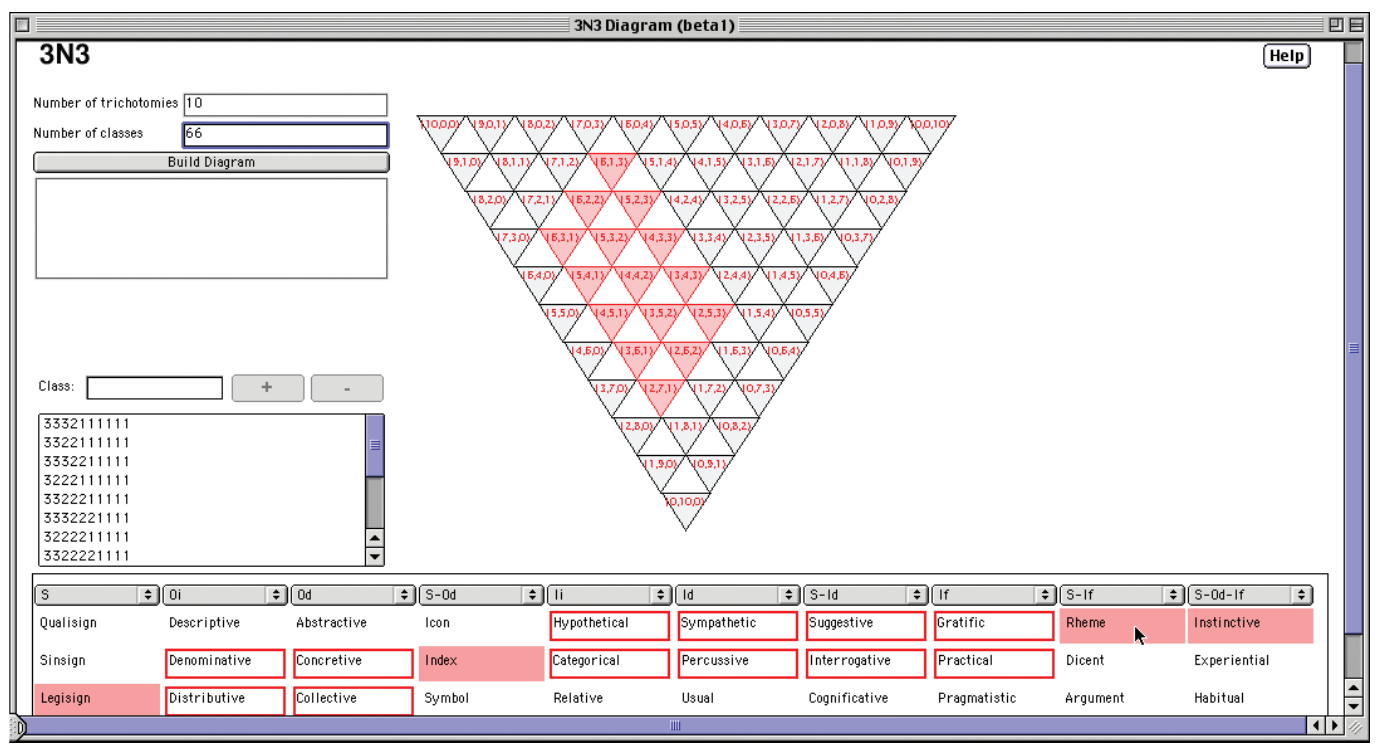


A partir da versão beta-1 de 3N3 tornou-se possível interagir com os diagramas construídos a partir da lista show class. Um campo para inserção de sequências numéricas foi colocado acima da lista, tendo ao lado um botão "mais" e um botão "menos". Com isso, tornou-se possível acrescentar classes à lista digitando sua sequência numérica neste campo, e clicando em seguida sobre o botão "mais" (Figura 91). O campo aceitava apenas sequências compostas pelos algarismos 1,2 e 3 , que obedeciam à regra $(x 1, x 2 \leq x 1, x 3 \leq x 2, \ldots x n+1 \leq x n)$ e cuja quantidade de elementos fosse igual à quantidade de tricotomias do diagrama em questão. Para excluir classes da lista, bastava selecioná-las e clicar no botão "menos" (Figura 92).

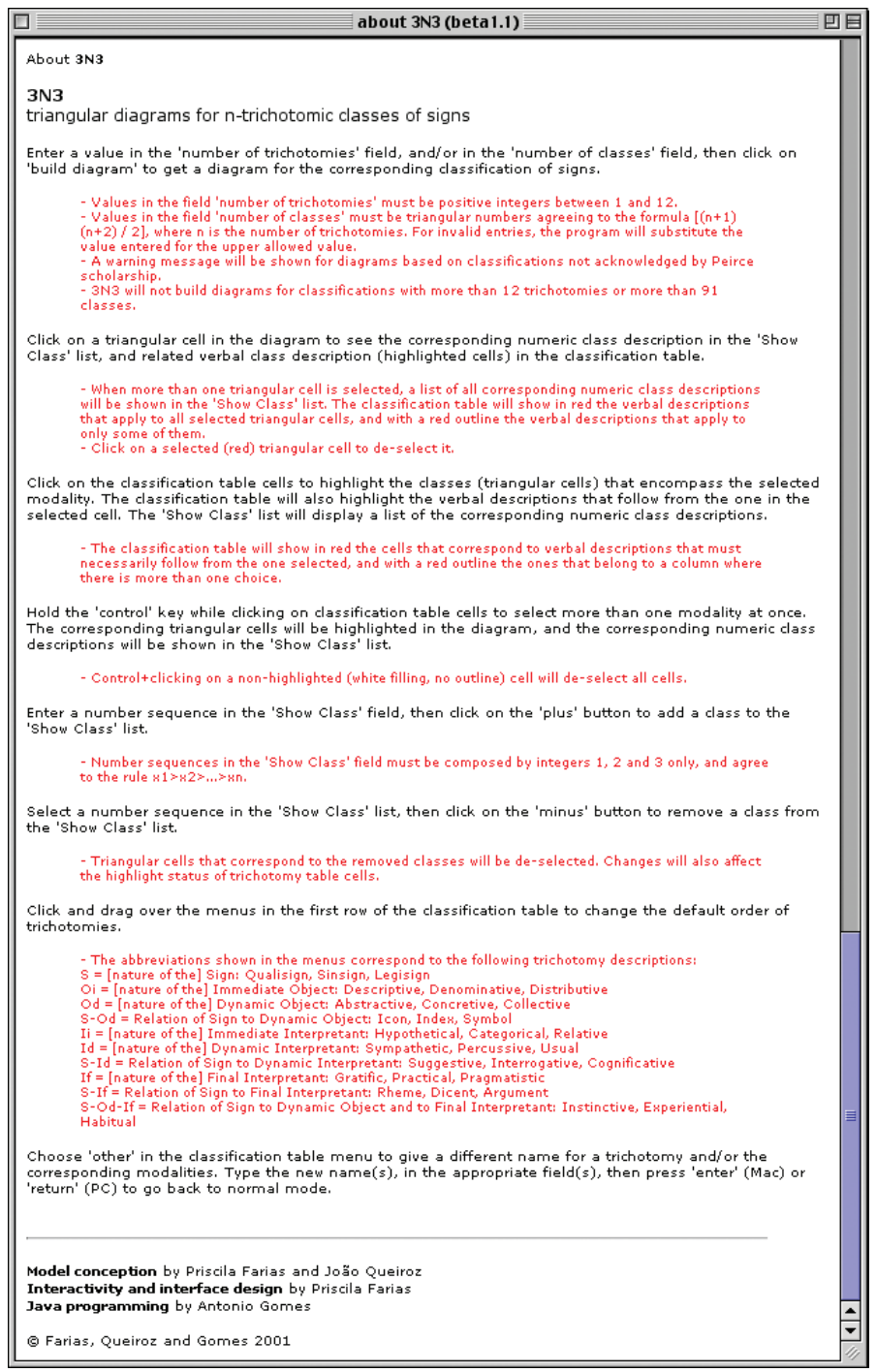

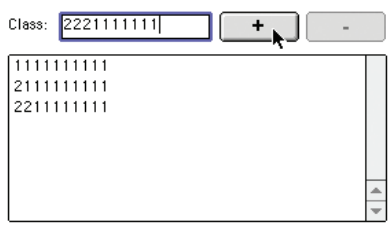

Figura 91. Inserindo uma classe na lista show class, na versão beta-1 de $3 N 3$,

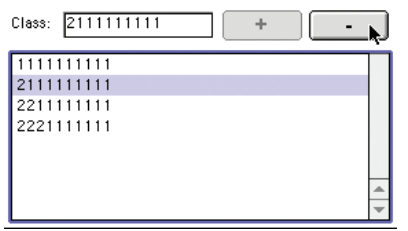

Figura 92. Excluindo uma classe da lista show class, na versão beta-1 de $3 N 3$. 
Ajuda

Assim como no 10cubes, no 3N3 também foi acrescentado um recurso de ajuda ao usuário, consistindo em um botão help localizado no canto superior direito da interface de entrada (Figura 78) e em uma página em html com créditos e informações básicas sobre o funcionamento do software (Figura 93).

Experimentação

Como vimos na Seção I.1.3, há controvérsias quanto à ordem das tricotomias envolvidas nas classificações em 28 e 66 classes de signo. A divisão em dez classes proposta no "Syllabus" de 1903 (EP 2: 289-99), por outro lado, é razoavelmente bem conhecida e abordada de forma bastante consistente pelos especialistas. Os recursos fornecidos por 3N3 permitem que diferentes abordagens sobre as classificações encontradas na literatura especializada sejam comparadas.

Os exemplos a seguir mostram como este software pode ser usado para comparar diversas posições, conflitantes, sobre as 28 e as 66 classes de signos. Para isso, partiremos do princípio de que, como sugerem alguns autores (MARTY 1990: 225-228; MARÓSTICA 1992: 117-120), é possível estabelecer correspondências entre as dez classes de signos descritas no "Syllabus" e as divisões em 28 e 66 classes. As dez classes servem, assim, como referência para estas comparações.

Experimentação - o diagrama de Welby e as 28 classes

A primeira suposição a ser examinada relaciona-se à correspondência entre o diagrama de Welby - um diagrama para dez classes desenhado por Peirce em um esboço de carta para Lady Welby no final de dezembro de 1908 (Figura 22) - e as dez classes de signos descritas no "Syllabus". No trecho dedicado à fase de conceitualização de $3 \mathrm{~N} 3$, chamamos atenção para o fato deste diagrama ser bastante similar aos diagramas triangulares para as 28 classes de signos construídos a partir de coordenadas triangulares. De fato, o diagrama de Welby possui o mesmo número de células triangulares apontando para baixo (28), embora apenas dez delas estejam ocupadas por classes. Uma vez que as classes descritas neste diagrama parecem não ser as mesmas encontradas no diagrama do "Syllabus" e, uma vez que existe indicação explícita às 28 classes em pelo menos outro manuscrito datado da mesma semana (carta enviada a Lady Welby datada de 23 de dezembro de 1908, Peirce 1977: 84-85, EP 2: 481), podemos perguntar se Peirce não teria 
em mente as 28 classes quando desenhou este diagrama. Além disso, podemos perguntar se há alguma relação entre as dez classes que aparecem no diagrama de Welby e as dez classes descritas no "Syllabus".

Para examinar esta suposição, iniciamos construindo um diagrama triangular para 28 classes de signos e identificando nele as posições ocupadas por classes no diagrama de Welby (comparar Figura 94 com Figura 23 e Figura 73). Na lista show class podemos observar que as classes selecionadas seguem um padrão peculiar, que pode ser descrito como $h 1=h 2=t 1$, $h 3=h 4=t 2, h 5=h 6=t 3 .{ }^{57}$

\section{N3}

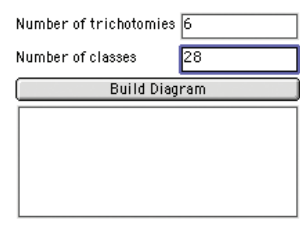

Show Class

\begin{tabular}{|l|l|}
\hline 111111 & \\
331111 & \\
333311 & \\
333333 & \\
221111 & \\
332211 & \\
333322 & \\
222211 & \\
332222 & \\
222222 & \\
&
\end{tabular}

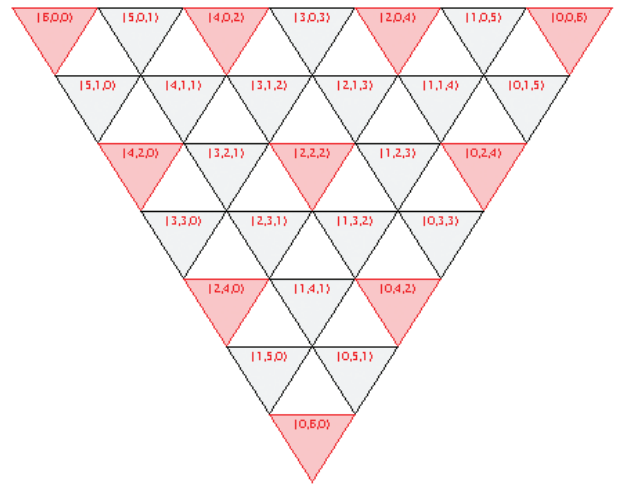

Se considerarmos que a ordem correta das tricotomias envolvidas na divisão em 28 classes é aquela fornecida por Peirce na carta de 23 de dezembro (PEIRCE 1977: 84-85, EP 2: 481), ou seja [h1=Od, h2=Oi, h3=S, h4=Ii, h5=Id, h6=If], só existe uma relação possível com as dez classes descritas no "Syllabus". Ela acontece a partir da terceira tricotomia da divisão 6-tricotômica (h3), que corresponde à primeira divisão 3-tricotômica $(t 1)$ descrita no "Syllabus": a natureza do signo, ou o signo em si mesmo (S). Cruzando as posições das classes do diagrama de Welby com as três modalidades da tricotomia $S$ no diagrama triangular para 28 classes, percebemos que entre as dez classes de Welby, entendidas como parte das 28 classes, existem três qualisignos (Figura 95), quatro sinsignos (Figura 96) e três legisignos (Figura 97).
57 A seguinte convenção será utilizada para descrever padrões na formação das classes:

- as tricotomias envolvidas em divisões 3-tricotômicas serão identificadas por $t n$; - as tricotomias envolvidas em divisões 6-tricotômicas serão identificadas por $h n$; e - as tricotomias envolvidas em divisões 10-tricotômicas serão identificadas por $d n$,

- onde $n$ indica a posição de uma tricotomia dentro da ordem de determinação.

Figura 94. Diagrama triangular para 28 classes com as 10 células que correspondem às posições de classes no diagrama de Welby (Figura 23) selecionadas. 
Figura 95. Diagrama triangular para 28 classes com os três qualisignos que correspondem a posições de classes no diagrama de Welby (Figura 23) selecionados.

Figura 96. Diagrama triangular para 28 classes com os quatro sinsignos que correspondem a posições de classes no diagrama de Welby (Figura 23) selecionados.
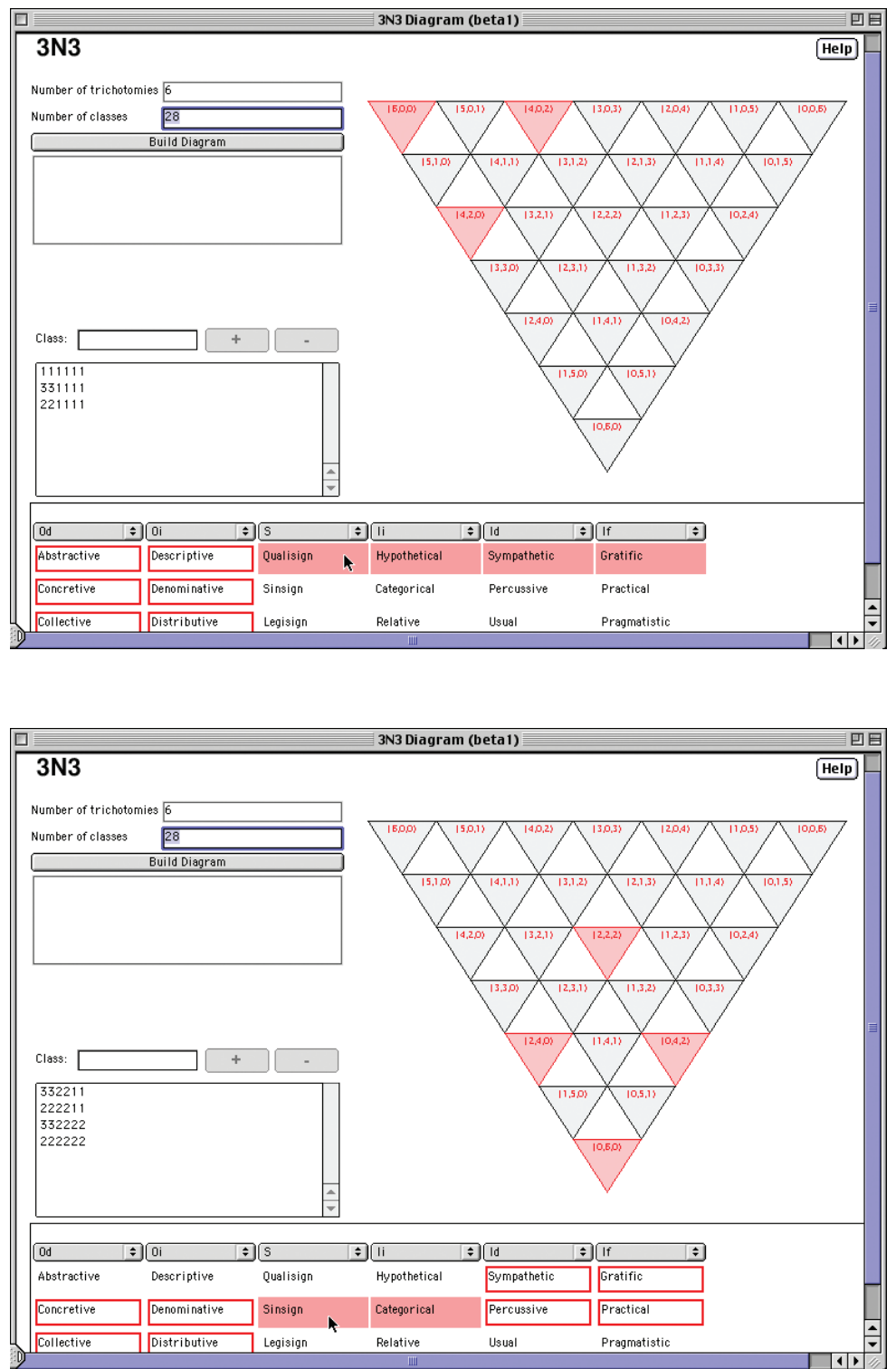


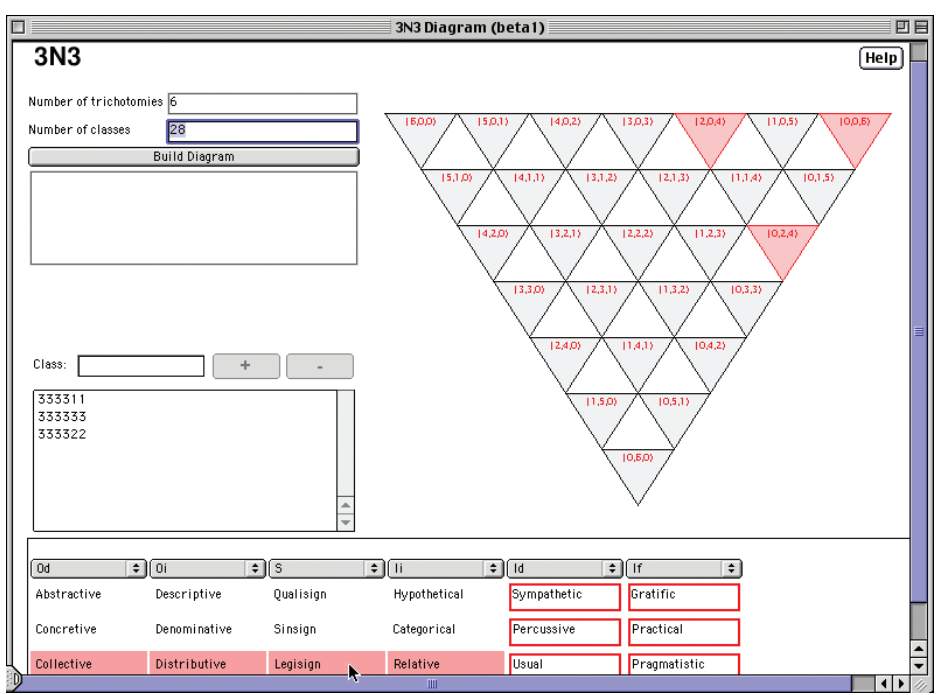

\section{Experimentação - a hipótese de Maróstica}

Para Maróstica (1992: 117-120), é possível localizar, entre aquelas que pertencem às divisões em 28 e 66, classes específicas que correspondem às dez classes apresentadas por Peirce no "Syllabus" de 1903. Segundo a autora, as tricotomias envolvidas na divisão em 28 classes são as mesmas utilizadas no exemplo anterior, mas em uma ordem de determinação diferente, $[\mathrm{h} 1=\mathrm{S}, \mathrm{h} 2=\mathrm{Oi}$, h3=Od, h4=Ii, h5=Id, h6=If]; as envolvidas na divisão em dez classes seriam [tl(S), t2(O), t3(I)]. ${ }^{58}$ Ela também argumenta que a relação entre as dez e as 28 classes

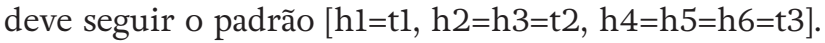

Existem apenas dez classes, entre as 28, que respeitam este padrão:

\section{1}

211111

222111

222222

311111

322111

322222

333111

333222

333333

Inserindo estas sequências na lista show class obtemos a Figura 98, que mostra a localização destas dez classes no diagrama para
Figura 97. Diagrama triangular para 28 classes com os três legisignos que correspondem a posições de classes no diagrama de Welby (Figura 23) selecionados.

58 Segundo Maróstica (1992: 115-116), nós devemos entender as dez classes como "combinações ... baseadas no tipo estático de definição do signo" dado por Peirce. Sendo assim, no lugar de S-Od teríamos apenas "O", e no lugar de S-If teríamos simplesmente "I". Ela afirma, contudo, que a combinação destas tricotomias resulta nas mesmas dez classes descritas por Peirce no "Syllabus" de 1903, inclusive no que se refere às modalidades expressas por estas tricotomias. 
Figura 98. A localização das dez classes dentro de um diagrama para 28 classes, segundo a suposição de Maróstica.
Figura 99. Um diagrama para 28 classes com a classe "322111" selecionada. Segundo a suposição de Maróstica, esta classe deveria corresponder ao "legisigno indexical remático” descrito por Peirce. as 28 classes. Cruzando estes dados percebemos que, segundo Maróstica, entre estas dez classes existem 1 qualisigno, 3 sinsignos e 6 legisignos, coerente com o que temos nas dez classes descritas no "Syllabus". Contudo, se levarmos em consideração as descrições verbais para estas classes, fornecidas pela tabela de tricotomias, veremos que a relação entre as dez classes obtidas por Maróstica e as dez classes descritas no "Syllabus" é bastante problemática. A classe 322111, por exemplo, que segundo a autora deveria corresponder ao "legisigno indexical remático", no "Syllabus", é descrita como um "legisigno denominativo concretivo hipotético simpatético grafítico" (Figura 99).
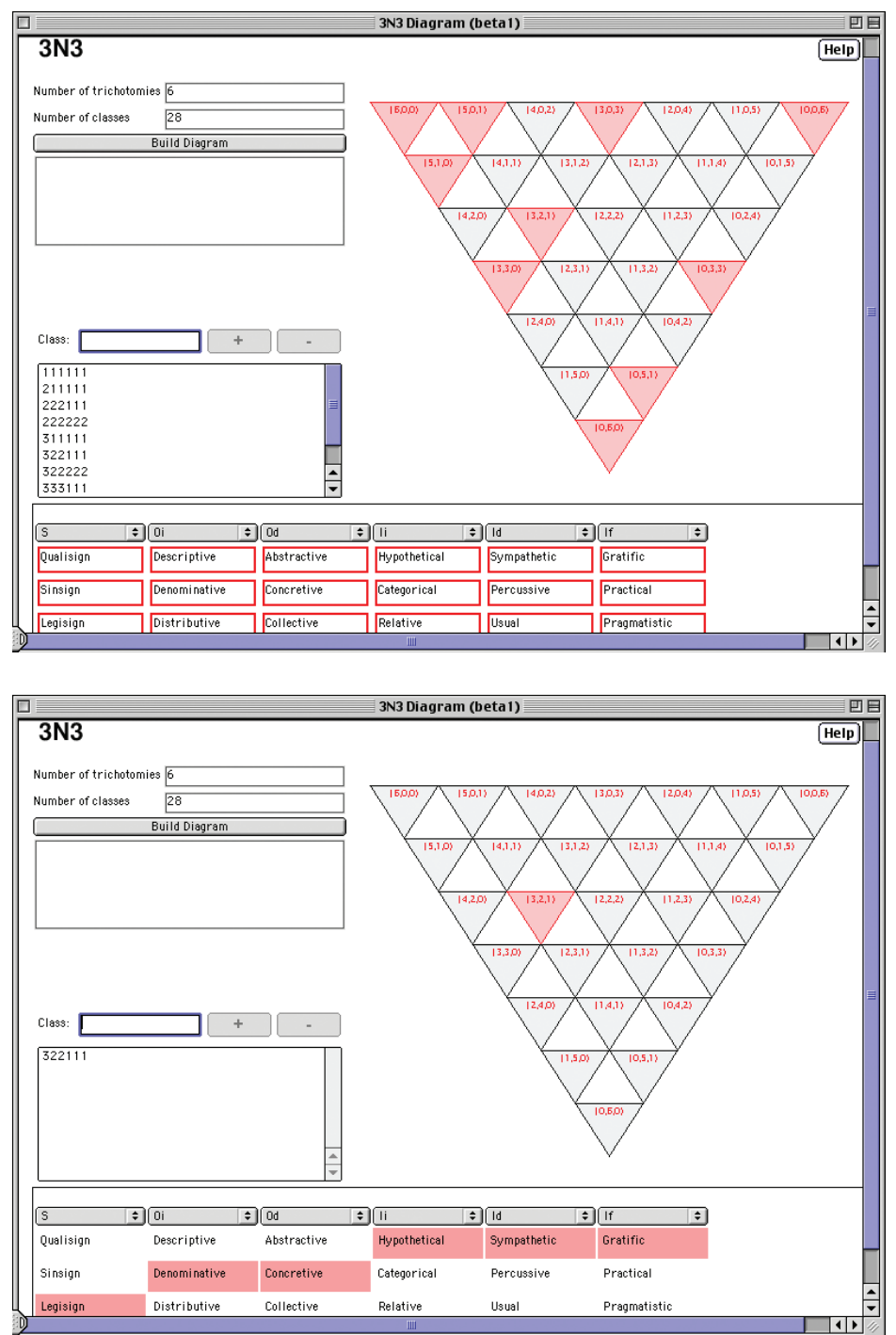
Maróstica (1992) propõe também um método para desenhar diagramas para divisões (dez, 28 e 66 classes de signos), com resultados bastante similares aos apresentados neste capítulo (Figura 38). O desenvolvimento de seus argumentos sugere que a relação entre as classificações possa ser estendida às 66 classes. Mas seu trabalho não vai muito além da exposição de uma sequência de tricotomias que não respeita aquelas propostas por Peirce, nem encontra respaldo entre especialistas: $S$ (signo), IOP (objeto imediato como objeto possível), IOA (objeto imediato como objeto atual), ION (objeto imediato como coisa necessária), DOP (objeto dinâmico como objeto possível), DOA (objeto dinâmico como objeto atual), DON (objeto dinâmico como coisa necessária), II (Interpretante Imediato), DI (interpretante dinâmico) e FI (interpretante final). Embora Maróstica não seja clara sobre a relação desta sequência com as divisões dos signos e menos ainda quanto às modalidades expressas por estas tricotomias, utilizando os recursos de 3N3 é possível construir um diagrama compatível com esta suposição e tentar localizar algumas classes (Figura 100). é a mesma ordem de determinação defendida por Müller (1994: 147). Para Marty (1990), diversos autores (WEISS; BURKS 1945; DELEDALLE; RÉTHORÉ 1979; JAPPY 1984) teriam compreendido mal o trecho da carta para Lady Welby onde Peirce fornece a ordem de determinação destas tricotomias (PEIRCE 1977: 8485, EP2: 481). Para Marty, devemos entender destinate como um sinônimo de final, e explicit como um sinônimo de immediate.

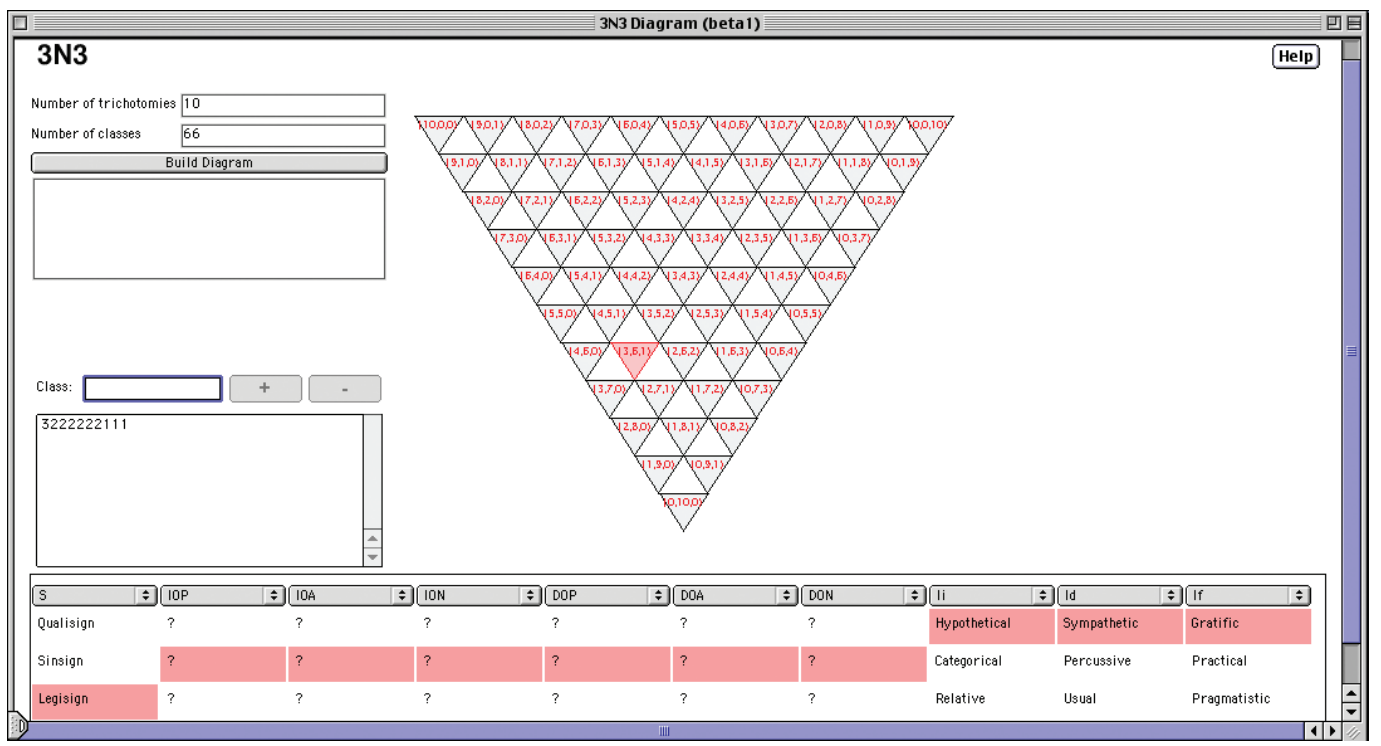

\section{Experimentação - a hipótese de Marty}

Como Maróstica, Marty (1990) também relaciona as dez e 28 classes de signos. Ele adota, contudo, uma ordem de determinação diferente para as seis tricotomias envolvidas: [hl $(\mathrm{Od})$, h2(Oi), h3(S), h4(If), h5(Id), h6(Ii)]. ${ }^{59}$ Segundo o autor, embora esta ordem de determinação, em que os "objetos" antecedem
Figura 100. Um diagrama para 66 classes, com a sequência de tricotomias proposta por Maróstica (1992) e com a classe "3222222111" selecionada. 
Figura 101. Diagrama para 28 classes com as duas classes 6-tricotômicas que, segundo Marty (1990: 225-228), correspondem à classe 3-tricotômica 321, selecionadas. o "signo", pareça estar em conflito com a ordem de determinação exposta no "Syllabus" (em que a "natureza do signo" antecede a "relação do signo com o objeto"), as 28 classes podem ser consideradas subdivisões das dez classes de signos apresentadas no mesmo artigo de acordo com o padrão [hl=tl, h3=t2, h4=t3] (MARTY 1990: 225-228). Neste caso, para cada uma das dez classes descritas no "Syllabus" deve-se encontrar uma ou mais correspondentes entre aquelas pertencentes à divisão em 28 tipos de signos.

Para localizá-las utilizando 3N3, iniciamos com um diagrama para 28 classes onde a tabela de tricotomias segue a ordem de determinação adotada por Marty. Em seguida, utilizamos o padrão proposto pelo autor para selecionar os grupos de classes que correspondem às dez classes 3-tricotômicas. Por exemplo, para encontrar o conjunto de classes 6-tricotômicas que corresponde à classe 321 , selecionamos a modalidade 3 da primeira coluna de tricotomias, a modalidade 2 da terceira coluna e a modalidade 1 da quarta coluna (Figura 101). A Figura 102 mostra a divisão das 28 classes segundo este princípio.

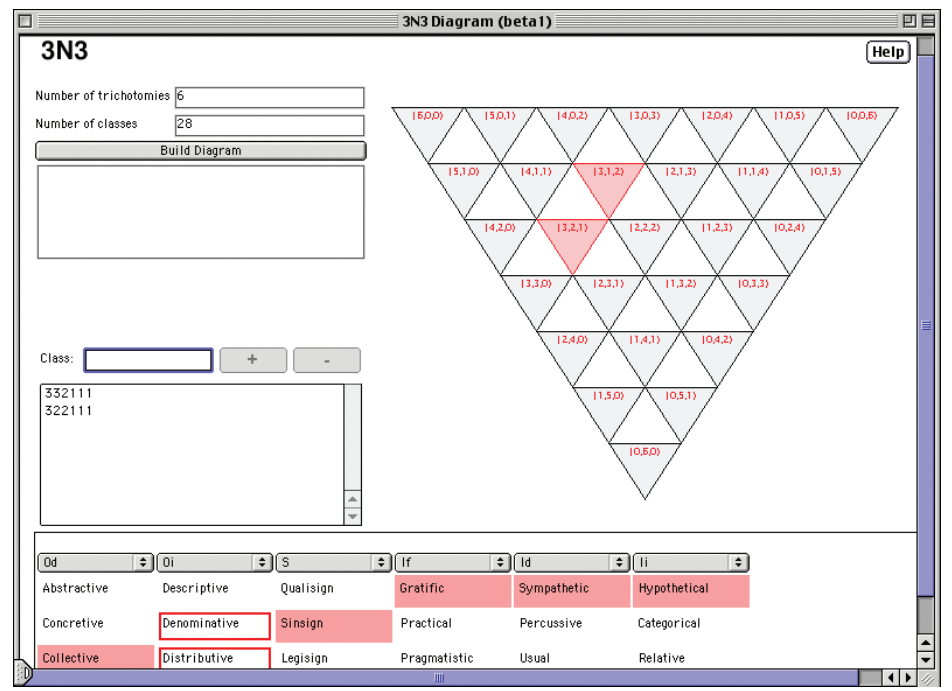




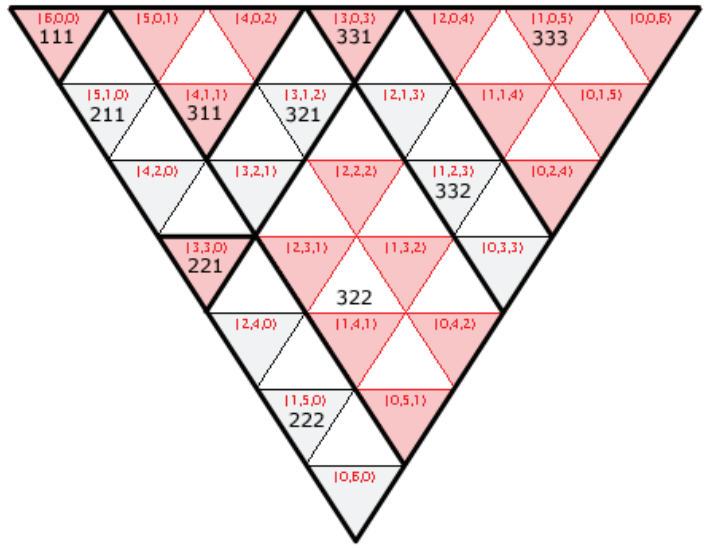

Ao estabelecer estas correspondências utilizando 3N3, fica imediatamente claro que, embora seja possível dividir as 28 classes em dez grupos segundo o padrão proposto por Marty, a relação entre estes conjuntos e as classes descritas no "Syllabus" é bastante problemática. Notamos, por exemplo, que o conjunto das classes 6-tricotômicas que, segundo Marty, é uma "subdivisão" dos legisignos indexicais remáticos (321) não possui nenhum legisigno, mas apenas sinsignos (ver tabela de tricotomias na Figura 101). Além disso, os conjuntos que correspondem aos sinsignos e aos legisignos icônicos (211 e 311) possuem apenas qualisignos, e aquele que corresponde aos legisignos indexicais dicentes (322) possui apenas sinsignos (Figuras 103, 104 e 105).

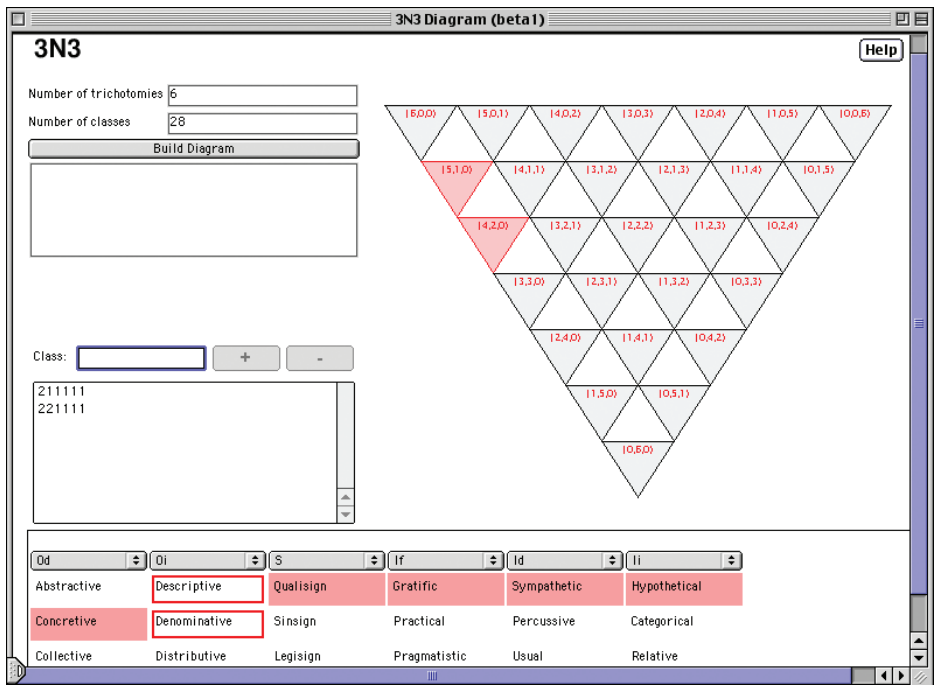

Figura 102. Diagrama para 28 classes mostrando os dez conjuntos de classes 6-tricotômicas que, segundo Marty (1990: 225-228), correspondem às dez classes 3-tricotômicas.

Figura 103. Diagrama para 28 classes com o conjunto de classes 6-tricotômicas que, segundo Marty (1990: 225-228), é uma subdivisão da classe 3-tricotômica 211 (sinsignos icônicos), selecionado. 
Figura 104. Diagrama para 28 classes com o conjunto de classes 6-tricotômicas que, segundo Marty (1990: 225-228), é uma subdivisão da classe 3-tricotômica 311 (legisignos icônicos), selecionado.
Figura 105. Diagrama para 28 classes com o conjunto de classes 6-tricotômicas que, segundo Marty (1990: 225-228), é uma subdivisão da classe 3-tricotômica 322 (legisignos indexicais dicentes), selecionado.
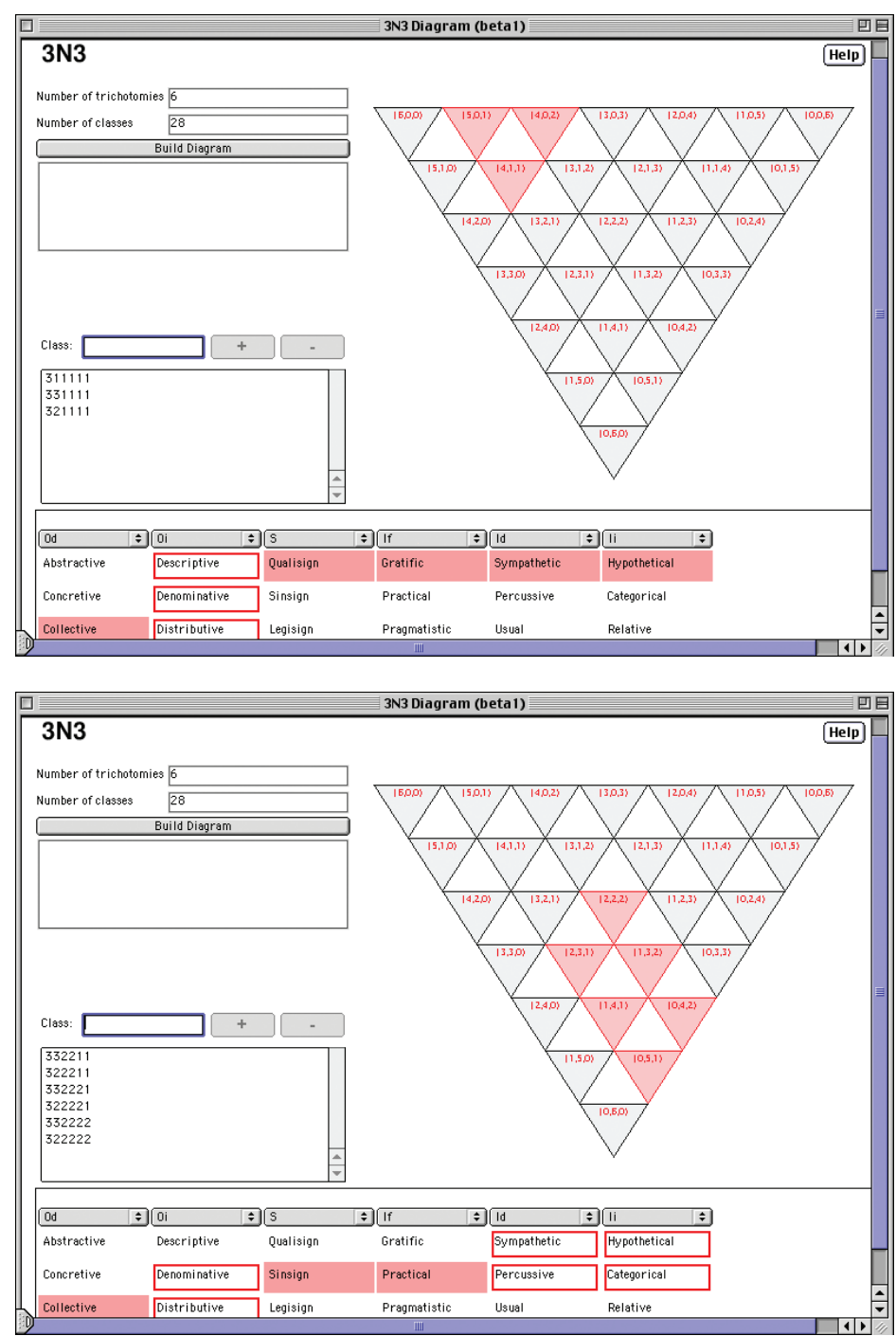

\section{Experimentação - relações entre as 3, as 6 e as 10 tricotomias}

Os problemas encontrados nas suposições de Maróstica e Marty derivam do fato destes autores buscarem uma relação entre as classes desconsiderando que existe apenas uma tricotomia em comum nas divisões em dez e 28 classes propostas por Peirce no "Syllabus" em 1903 e na carta para Lady Welby de 23 de dezembro de 1908. Se, como discutimos nas Seções I.1.2 e I.1.3, estas tricotomias são $<S, S-O d$, S-I $\beta$, para as dez classes do "Syllabus", e $<S, \mathrm{Oi}, \mathrm{Od}$, Ii, Id, If $>$, para as 28 classes da carta de Welby, então, independentemente da ordem de determinação, existe apenas 
uma tricotomia $(S)$ que está envolvida em ambas as classificações. Por outro lado, como discutimos nos mesmos capítulos, a divisão dos signos em 66 classes envolve os conjuntos de tricotomias e mais uma décima $(S-O d-I f)$. Mas há divergência entre os especialistas quanto à ordem de determinação destas dez tricotomias.

Podemos utilizar 3N3 para visualizar e testar as consequências de diferentes ordens de determinação nas relações entre as 66 e as dez classes de signos. Para isso, iniciamos construindo um diagrama para 66 classes onde a ordem das tricotomias na tabela segue a "lista dos dez aspectos de acordo com os quais as principais divisões de signos são determinadas" (L463: 134, 150, CP 8.344, EP 2: 482-483) fornecida por Peirce: S, Oi, Od, S-Od, Ii, Id, S-Id, If, S-If, S-Od-If. A partir daí, ao clicar nas células da tabela que pertencem às colunas das tricotomias presentes na divisão em dez classes (S, S-Od e S-If) podemos identificar, um a um, os conjuntos de classes 10-tricotômicos que correspondem às classes descritas no "Syllabus" de 1903. É possível identificar, por exemplo as classes 10-tricotômicas que correspondem aos legisignos indexicais remáticos (321) nesta configuração (Figura 90).

Em seguida, repetimos o protocolo partindo de diferentes ordens de determinação. A Figura 106 mostra o que ocorre ao localizarmos a mesma classe em um diagrama onde as tricotomias estão dispostas segundo a ordem de determinação defendida por Müller (1994: 147): Od, Oi, S, If, Id, Ii, S-Od, S-If, $S$-Id, S-Od-If. Notem que, embora as tricotomias referentes à divisão em dez classes (S, S-Od e S-If) permaneçam na mesma posição relativa (em ambos os casos, $S$ precede $S-O d$, que precede $S$-If), as diferenças na ordem de determinação das sete tricotomias restantes têm consequências tanto para a quantidade quanto para a composição das classes 10-tricotômicas que compõem os conjuntos relacionados às dez classes. Por exemplo, diferente da ordem de tricotomias exposta na "lista dos dez aspectos", a ordem defendida por Müller (1994) exclui a existência de legisignos indexicais remáticos distributivos, mas inclui um legisigno indexical remático pragmatístico (comparar as tabelas das Figuras 90 e 106).

Outro exemplo é o conjunto de classes 10-tricotômicas que correspondem aos "qualisignos [icônicos remáticos]" do "Syllabus". Seguindo a ordem de tricotomias fornecida pela "lista dos dez aspectos" (L463: 134, 150, EP 2: 482-483), temos apenas um qualisigno (Figura 107). Seguindo a ordem de determinação defendida por Müller (1994: 147) ou a ordem adotada por Lieb (1977: 164, apoiado em Peirce 1977: 84-85, 
Figura 106. Diagrama triangular para 66 classes de signos, com as células "legisign", "index" e "rheme" da tabela selecionadas a partir da ordem de determinação defendida por Müller (1994: 147).
EP 2: 481) - Od, Oi, S, Ii, Id, If, S-Od, S-Id, S-If, S-Od-If-, temos seis qualisignos (Figuras 108 e 109). O número de classes 10-tricotômicas que correspondem aos qualisignos nestas duas últimas ordens de determinação é igual porque a tricotomia $S$ está localizada na mesma posição. A composição das classes 10-tricotômicas dos dois conjuntos também é idêntica devido ao fato das três primeiras tricotomias serem as mesmas, e a terceira $(S)$ determinar as modalidades seguintes (1 ou "primeiras", em termos cenopitagóricos).

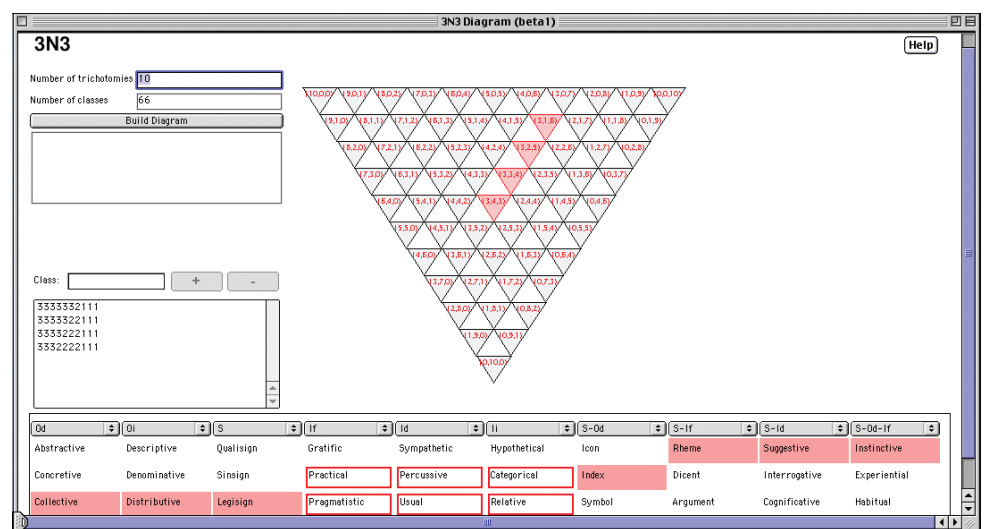

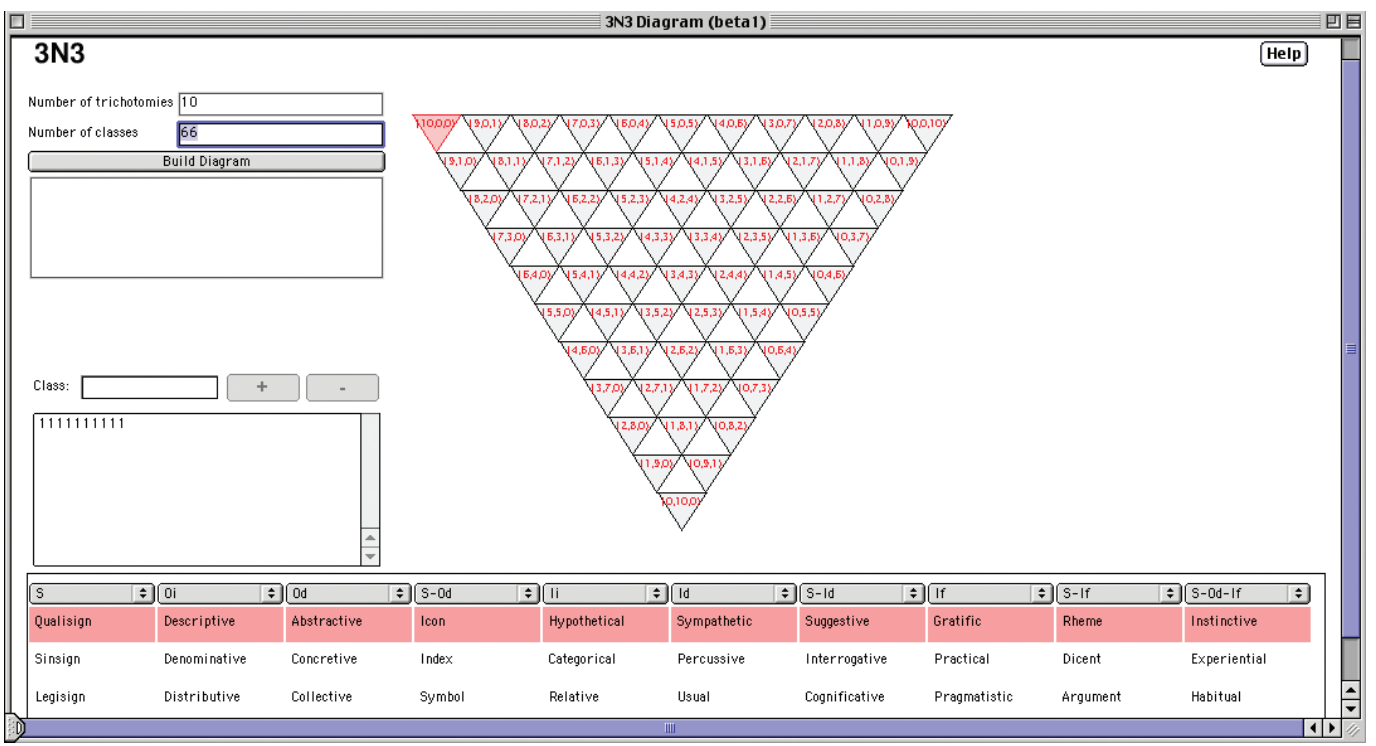

Figura 107. Diagrama triangular para 66 classes de signos, configurado de acordo com a ordem de determinação de Peirce na "lista dos dez aspectos" (L463: 134, 150, EP 2: 482-483), mostrando o conjunto das classes 10-tricotômicas que correspondem aos qualisignos descritos no "Syllabus" de 1903. 


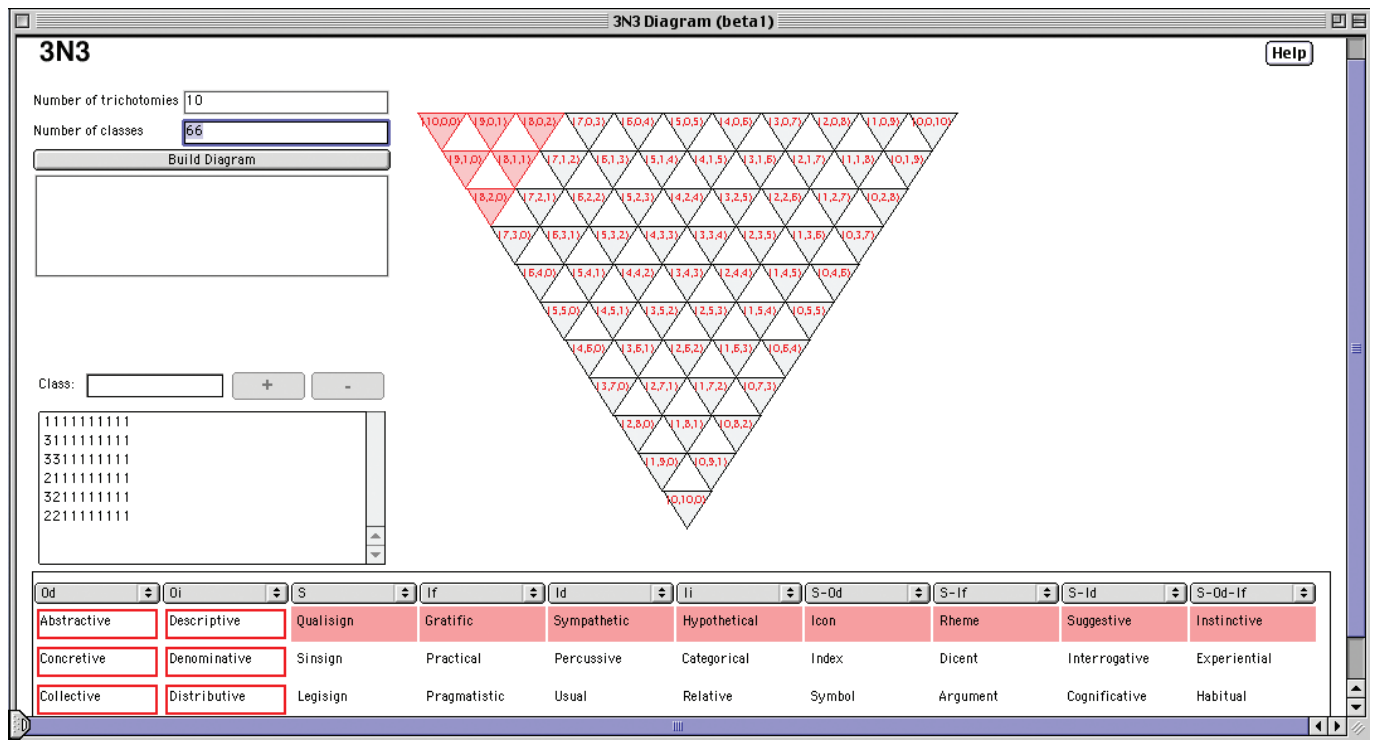

Figura 108. Diagrama triangular para 66 classes de signos, configurado de acordo com a ordem de determinação de Müller (1994: 147), mostrando o conjunto das classes 10-tricotômicas que correspondem aos qualisignos descritos no "Syllabus" de 1903.

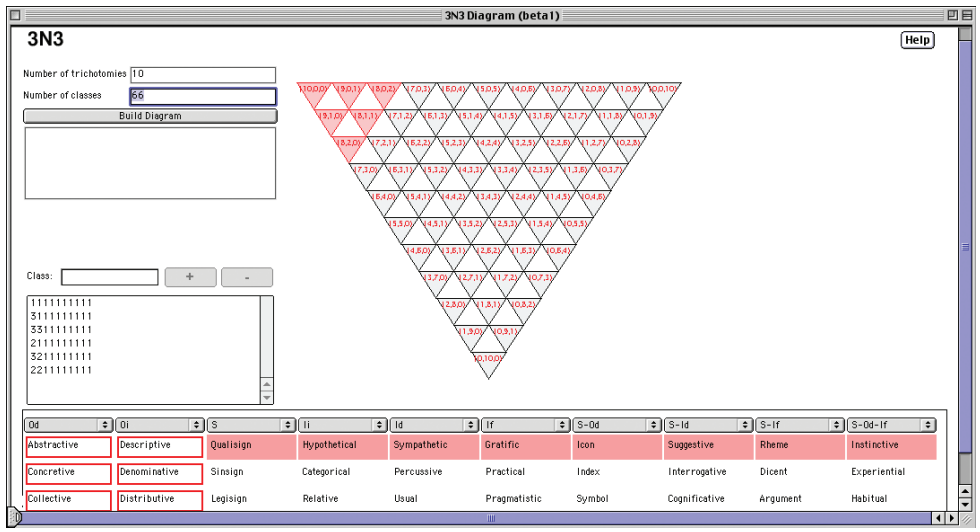

Figura 109. Diagrama triangular para 66 classes de signos, configurado de acordo com a ordem de determinação de Lieb (1977: 164), mostrando o conjunto das classes 10-tricotômicas que correspondem aos qualisignos descritos no "Syllabus" de 1903. 
